\title{
Smart education framework
}

\author{
Kadir Alpaslan Demir * (B)
}

*Correspondence:

kadiralpaslandemir@gmail.

com

Independent Researcher,

Istanbul, Turkey

\begin{abstract}
Advances in information technologies present opportunities for novel approaches, methods, and tools for new or improved education and training practices. Furthermore, these technologies are enabling a shift in the education paradigm. Based on an investigation of a wide range of information technologies supporting smart education, we developed a Smart Education Framework. The framework conceptually structures the information technologies in a layered architecture. We also developed a smart education design approach based on the framework. Furthermore, we show how to use the framework and design approach to develop a specific course or lecture design. To validate the smart education framework, we examined smart education systems reported in the literature. To identify smart education systems, we conducted a systematic literature search. The literature search results show that the smart education framework has the ability to describe smart education systems. This study contributes to the current literature with a smart education framework. The smart education framework will guide future smart education system designs.
\end{abstract}

Keywords: Smart education, Smart education framework, Educational information technologies, Smart education design, Smart learning, Smart learning framework, Smart learning design

\section{Introduction}

Recent advances in information technologies are affecting our education and training approaches, methods, practices, and tools (Kaufmann, 2003; Palloff \& Pratt, 2002; Shoikova et al., 2017; Zhu et al., 2016a, 2016b). Increasing internet speeds and storage areas together with the advances in cloud computing technologies, making the information available to everybody, from everywhere, at all times. Traditional training and education methodologies, in which the instructor explains the subject in the classroom and the students complete the exercises at home, are replaced by new learning approaches such as distant learning, mobile learning (m-learning), personalized learning, flipped and blended learning, social collaborative learning, game-based learning, etc. (Erkollar \& Oberer, 2016; Güzer \& Caner, 2014; Knight \& Wood, 2005; Lage et al., 2000; Oberer, 2016; Prince, 2004; Rakow, 2007; Strayer, 2012). Information and communication technologies are creating the potential for more self-paced, interactive, and personalized learning. As new information technologies are introduced, we are moving from traditional education towards smart education (Bajaj \& Sharma, 2018; Zhu et al., 2016b).

(c) The Author(s), 2021. Open Access This article is licensed under a Creative Commons Attribution 4.0 International License, which permits use, sharing, adaptation, distribution and reproduction in any medium or format, as long as you give appropriate credit to the original author(s) and the source, provide a link to the Creative Commons licence, and indicate if changes were made. The images or other third party material in this article are included in the article's Creative Commons licence, unless indicated otherwise in a credit line to the material. If material is not included in the article's Creative Commons licence and your intended use is not permitted by statutory regulation or exceeds the permitted use, you will need to obtain permission directly from the copyright holder. To view a copy of this licence, visit http:// creativecommons.org/licenses/by/4.0/. 
The students in the twenty-first century are different than the students of the past. Oblinger and Oblinger (2005) identify the generation born after 1982 as net generation or "Millennials". Unlike many prior generations, this generation grew up with technology. Some of the characteristics of college-aged millennials are listed in Table 1.

Technology has significant impacts on society. Furthermore, technology is changing faster than ever. Technological innovations impact our children as well. As their characteristics indicate that millennials are quite different than non-millennials. The instructors dealing with millennials have to be aware of these characteristics. The current learning environments have to be redesigned based on the strengths and weaknesses of these students. We need learning environments that are more suitable for the current and following generations. The smart education vision should help to achieve this requirement and overcome the shortcomings of the current education methods and systems. To realize the smart education vision, we need to develop new or improved teaching and learning techniques along with a coherently designed set of educational information and communication technologies. Smart education frameworks are essential for smart education implementations. In this work, we developed such a smart education framework. This framework has a layered structure. New or improved teaching methods are at the core layer. We categorize educational information and communication technologies into three categories. These are essential/transforming technologies, enriching technologies, and supportive technologies. These categories form the layers of the smart education framework. In the following sections, we explain the framework and how the framework is used for smart education designs. We also provide two examples of smart education designs. To validate the framework, we conducted a systematic literature review investigating smart education system (SES) implementations and proposals. Our analysis shows that the smart education framework has the capability to describe all identified SESs as the result of the literature search.

In "Smart education" section, we discuss the concept of smart education. Next, we list trending educational technologies enabling smart education. In "Smart education

Table 1 Characteristics of college-aged Millennials

\begin{tabular}{|c|c|}
\hline Digitally literate & Millennials are digitally literate \\
\hline Multitasking & $\begin{array}{l}\text { Millennials are able to multitask rather than do a single task. They can } \\
\text { move quickly from one task to another }\end{array}$ \\
\hline Prefer visual media over text & $\begin{array}{l}\text { Millennials prefer visual media over text. They are relatively poor in text } \\
\text { literacy }\end{array}$ \\
\hline Prefer internet search over library search & Millennials prefer internet search over library search \\
\hline Connected & Millennials stay connected. They crave connectivity \\
\hline Immediacy & Millennials require fast responses. They have a sense of immediacy \\
\hline Experiential & $\begin{array}{l}\text { Millennials are experiential. Therefore, they prefer learning by doing } \\
\text { rather than by being told what to do }\end{array}$ \\
\hline Social and team player & Millennials are social and often prefer to learn and work in teams \\
\hline Achievement-oriented & Millennials are very achievement-oriented \\
\hline Interactivity and engagement & $\begin{array}{l}\text { Millennials require interactivity and engagement from learning envi- } \\
\text { ronments. Otherwise, they lose focus }\end{array}$ \\
\hline
\end{tabular}


framework" section, we present a smart education framework that conceptually structures the technologies in a layered architecture. "Smart education design" section describes a smart education design approach with examples. In "Validate the framework" section, we present the findings of our systematic literature search to validate the framework. Finally, we present discussions and conclusions.

\section{Smart education}

We define smart education as the "effective and coherent use of information and communication technologies to reach a learning outcome using a suitable pedagogical approach". An earlier definition provided by Zhu and He (2012) is that "the essence of smarter education is to create intelligent environments by using smart technologies, so that smart pedagogies can be facilitated as to provide personalized learning services and empower learners to develop talents of wisdom that have better value orientation, higher thinking quality, and stronger conduct ability". Another definition of smart education is "the concept of learning in the digital age" (Zhu et al., 2016b). According to Bajaj and Sharma (2018), smart education is "about providing personalized learning, anywhere and anytime. Moreover, they state that smart education is about taking learning outside the traditional classrooms; and is an activity that can be done anywhere and anytime". Jang defines smart education as "an educational system that allows students to learn by using up-to-date technology and it enables students to study with various materials based on their aptitudes and intellectual levels" (Jang, 2014). Smart learning environments, sometimes used to refer to smart education, "represent a new wave of educational systems, involving an effective and efficient interplay of pedagogy, technology and their fusion towards the betterment of learning processes" (Shoikova et al., 2017). Notice that smart education is not just about technology. It is also about new teaching and learning approaches.

Several countries started smart education initiatives or programs as listed in Table 2. A holistic concept of smart education in Korea includes Self-directed, Adaptive, Motivated, Resource-Free, Technology embedded education (Kim et al., 2013). Standards are also essential for the development of smart education since it heavily relies on information and communication technologies (Hoel \& Mason, 2018). International Standards Organization (ISO) has a group (ISO/IEC JTC 1/SC 36) to support the development of standards for "Information technology for learning, education, and training". 40 standards were developed under the direct responsibility of the group and more standards are

Table 2 Smart education initiatives and programs

\begin{tabular}{lll}
\hline Country & Initiative/program name & References \\
\hline Malaysia & Malaysian smart school implementation plan & Chan (2002) \\
Singapore & Intelligent nation (iN2015) master plan & Hua (2012) \\
South Korea & SMART education project & Kim et al. (2013) \\
Finland & Systemic learning solutions (SysTech) & Kankaanranta and Mäkelä (2014) \\
Arab Countries & ALECSO \& ITU smart learning framework & Jemni and Khribi (2017) \\
Australia & Smart student-centric education system & Zhu et al. (2016b) \\
United Arab Emirates & Mohammed Bin Rashid smart learning program & Lavine and Croome (2018) \\
& (MBRSLP) & \\
\hline
\end{tabular}


in development (International Standards Organization 2020). International associations such as the International Association of Smart Learning Environments are being formed to support the development of smart learning environments (http://iasle.net/). Various telecommunications and information technology companies started to invest in the education business. Technology giants such as IBM (2009) and Samsung (2013) are developing information technology architectures and solutions for smart education systems.

Alimisis (2013) criticizes that "most uses of technologies in schools today do not support the 21st-century learning skills. In many cases, new technologies are simply reinforcing old ways of teaching and learning." While smart education requires the use of information technologies, we believe smart education also encompasses a paradigm shift from traditional education and training practices to more advanced approaches and practices in line with the digital age. Therefore, new or improved learning and teaching approaches are among the essential elements of smart education. Our view of essential elements of smart education differs from the view of Zhu and his colleagues. Our view is presented in Fig. 1.

The characteristics of the essential elements will not be the same as in traditional education. They will evolve as smart education evolves. We briefly list and discuss the characteristics of millennials, in other words, learners of the digital age, in the previous section. The evolving characteristics of other essential elements require a thorough investigation.

In a smart education environment, the learner should be autonomous and collaborative in addition to being an efficient technology user. Instructional design is important both in traditional education and smart education. Today, direct instruction is the predominant teaching method. However, in modern approaches, the facilitator role of the educator is becoming significant. One notable role of educators in smart education is technological support. The teachers/educators should also be able to provide technical support to students if needed. Note that just like learners, educators should be effective

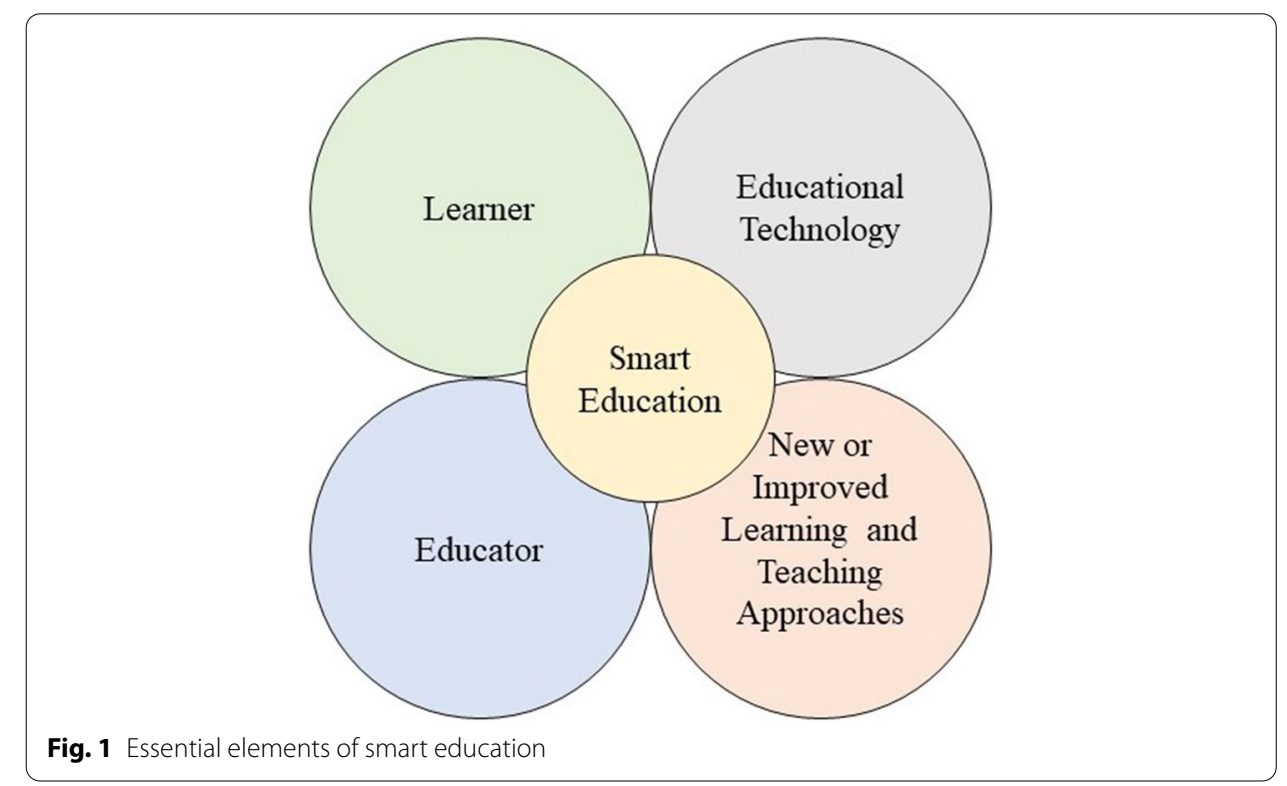


technology users. In a smart education environment, connectivity is an important distinguishing characteristic of the educational technology supporting education (Klopfer et al., 2002). In traditional face-to-face teaching, connectivity is often limited. Technologies such as web 2.0 provide enhanced connectivity between the learner and teacher. Ubiquity is as important as connectivity. Internet and mobile technologies provide ubiquitous access to information and knowledge. Ubiquitous educational technologies provide significant opportunities to geographically disadvantaged students. Various studies indicate that the learning process may vary depending on the learner (El Janati et al., 2018). Therefore, more effective learning can be achieved via personalized learning. Adaptive learning system research is gaining attention in recent years. According to the International Association of Smart Learning Environments, a smart learning environment can be considered "smart when it makes use of adaptive technologies or when it is designed to include innovative features and capabilities that improve understanding and performance." Smart education also offers new opportunities for providing personalized education and training to people with disabilities (El Janati et al., 2018).

\section{Enabling information technologies for smart education}

Information technologies are advancing at unprecedented speeds. New technologies, devices, applications, tools, and most importantly new ways of thinking are being introduced every day. Naturally, most of these have effects on educational and training practices at different levels. Table 3 lists some of the main information technologies enabling smart education.

There will be other technologies that support smart education. There is abundant literature on these technologies. Discussing all these information technologies is the subject of a review paper rather than a research paper.

\section{Related work}

In this section, we discuss various existing smart education or learning frameworks. Furthermore, we compare these with each other.

Zhu and his colleagues developed a smart education framework (Zhu et al., 2016a). The three essential elements in the smart education environment are learner presence, teaching presence, and technological presence (Zhu et al., 2016a). Zhu and his colleagues' smart education framework focuses on the elements of smart education. This framework is important in the sense that it highlights the elements, their characteristics, and their role in smart education.

Arab League Educational, Cultural and Scientific Organization (ALECSO) is an organization working within the Arab League consisting of 22 Arab countries (Jemni \& Khribi, 2017). ALECSO coordinates and contributes to several projects and activities in the Arab region to promote education, culture, and science. ALECSO ICT Department proposed a framework for smart learning. This smart learning framework (Jemni \& Khribi, 2017) has three key dimensions: open learning, mobile technology, and cloud computing. In each dimension, several projects are being developed. The ALECSO mobile initiative includes ALECSO Apps Store, ALECSO Apps Editor, ALECSO Apps Award, ALECSO Apps training programs. ALECSO with support from the International Telecommunication Union (ITU) Arab regional office aims at promoting cloud computing 
Table 3 Enabling information technologies for smart education

\begin{tabular}{|c|c|}
\hline Information technology & Definition \\
\hline Learning management systems & $\begin{array}{l}\text { Learning management systems are software applications or systems designed } \\
\text { to create, communicate, manage, and deliver education and training pro- } \\
\text { grams }\end{array}$ \\
\hline Smart classrooms & $\begin{array}{l}\text { Smart classrooms are physical educational environments supported with } \\
\text { information and communication technologies. Smart classrooms may utilize } \\
\text { ambient intelligence technology }\end{array}$ \\
\hline Virtual classrooms & $\begin{array}{l}\text { Virtual classrooms are educational environments in which educators and } \\
\text { learners meet virtually }\end{array}$ \\
\hline Cloud computing technology & $\begin{array}{l}\text { National Institute of Standards and Technology defines Cloud computing as } \\
\text { on-demand access to a shared pool of computing resources. The technology } \\
\text { enabling services on the cloud is called cloud computing technology }\end{array}$ \\
\hline Extended reality (XR) & $\begin{array}{l}\text { Extended reality is the term referring to all real and virtual combined (immer- } \\
\text { sive) environments in the spectrum including augmented reality (AR), virtual } \\
\text { reality (VR), and mixed reality (MR) }\end{array}$ \\
\hline Virtual environments & $\begin{array}{l}\text { A virtual environment is a computer-generated environment to replace the } \\
\text { real environment with a virtual one }\end{array}$ \\
\hline Augmented reality & $\begin{array}{l}\text { Augmented reality is the technology dealing with enhancing the user's sense } \\
\text { of the physical world with computer-generated sensory data in real-time }\end{array}$ \\
\hline Web $2.0+$ & $\begin{array}{l}\text { Web 2.0+ are technologies after Web 1.0. After Web 1.0, web technologies } \\
\text { offer interactive, semantic, and intelligent web services }\end{array}$ \\
\hline Social networks & $\begin{array}{l}\text { Social networking sites may be defined as the online platforms enabling social } \\
\text { interactions between users having profiles }\end{array}$ \\
\hline Educational resources & $\begin{array}{l}\text { Any type of learning and teaching material including educational presenta- } \\
\text { tions, e-books, interactive books, academic and corporate video tubes, etc. If } \\
\text { these resources are open to the public then they are called open educational } \\
\text { resources otherwise they are private to specific institutions }\end{array}$ \\
\hline Academic and corporate tubes & $\begin{array}{l}\text { Academic or corporate tubes are online video-sharing platforms for education } \\
\text { and training purposes }\end{array}$ \\
\hline E-books and interactive books & $\begin{array}{l}\text { E-books and interactive books are digital books enhanced with user interac- } \\
\text { tion ability }\end{array}$ \\
\hline Mobile technology & $\begin{array}{l}\text { Mobile technology is the information and communication technology ena- } \\
\text { bling portable mobile devices }\end{array}$ \\
\hline Serious games & Serious games are computer games used for instructional purposes \\
\hline Learning and academic analytics & $\begin{array}{l}\text { Learning analytics is about the collection, measurement, and analysis of data } \\
\text { about learning activities. Academic analytics utilizes business intelligence } \\
\text { tools and strategies to guide educational decision-making }\end{array}$ \\
\hline Educational data mining & $\begin{array}{l}\text { Educational data mining is to analyze data obtained from educational environ- } \\
\text { ments to understand patterns of learner behavior and to improve educational } \\
\text { settings }\end{array}$ \\
\hline Educational robots & Educational robots are robots used for educational and training purposes \\
\hline Gesture-based computing & $\begin{array}{l}\text { Gesture-based computing is the technology aimed at understanding human } \\
\text { gestures }\end{array}$ \\
\hline Ambient intelligence & $\begin{array}{l}\text { Ambient intelligence is an emerging paradigm that brings intelligence into } \\
\text { our lives with the help of intelligent interfaces and smart environments }\end{array}$ \\
\hline
\end{tabular}

in the use of education. Therefore, they start the ALECSO Cloud Computing Project. ALECSO promotes Open Learning with several projects and initiatives. Open Learning effort includes Open Book Initiative, collaboration on regional and international Open Educational Resources (OER) activities, ALECSO OER project, ALECSO Massive Open Online Courses (MOOCs) Project. ALECSO's smart learning framework is actually a combination of projects and activities to promote the use of ICT's in the educational domain.

Bajaj and Sharma proposed a smart education framework stressing the importance of adaptive learning in smart education (Bajaj \& Sharma, 2018). According to them, 
adaptivity is an essential need in today's educational environment. The goal of adaptive educational systems is to customize the educational content and learning paths of students. They proposed a framework in which students interact with a virtual teacher on the cloud and based on various learning theories and using artificial intelligence technology, the system generates personalized content and learning paths. Bajaj and Sharma's Smart Education Framework proposal has a technology view with a focus on adaptive learning.

The smart education framework developed within this study focuses on the role of various information and communication technologies in smart education. Furthermore, it stresses the importance of new or improved teaching and learning approaches. The framework highlights the need for a coherent combination of ICT technologies with appropriate teaching and learning approaches.

All these smart education or learning frameworks focus on different dimensions of smart education. Zhu and his colleagues' smart education framework focuses on smart education elements. ALECSO's smart learning framework focus on the use of open education resources in combination with mobile and computing technology with a number of projects. The smart education framework proposed in this study focus on the coherent design of educational technologies and with appropriate teaching and learning approaches. These frameworks complement each other. For example, Zhu and his colleagues' framework provides a smart education essential elements view, ALECSO's framework provides a project-based view, our framework provides a generic smart education design view. These frameworks are not competing with each other but they provide different perspectives. They focus on different aspects of smart education. As a result, these frameworks help develop and improve the concept of smart education. Furthermore, they provide the necessary conceptual infrastructure for smart education design and utilization.

Table 4 presents a comparison of smart education and learning frameworks'

\section{Smart education framework}

Based on an investigation of a wide range of information technologies supporting smart education, we developed a smart education framework as presented in Fig. 2. The framework is constructed in a layered architecture. New or improved teaching methods are at the core of smart education. The outer layers support the core layer in the realization of smart education. The purpose of each layer is described.

\section{New or improved learning/teaching approaches (core layer)}

In the 2018 US-China Smart Education Conference, one of the common themes was the structure of education is changing. These changes include "integrating new technologies, new pedagogical approaches, and new learning spaces and places" (Spector, 2018). We believe new or improved learning/teaching methods are at the essence of smart education. These new or improved teaching methods include approaches such as personalized learning, flipped learning, blended teaching, game-based learning, case-based learning, etc. The use of traditional teaching and learning approaches supported by information technologies will not be adequate for smart education. Consider the use of computers in education and training. Computers are among the most influential innovations 
Table 4 Smart Education and Learning Frameworks

\begin{tabular}{|c|c|c|c|}
\hline Framework & Framework focus & Framework goal & References \\
\hline $\begin{array}{l}\text { Smart education frame- } \\
\text { work }\end{array}$ & $\begin{array}{l}\text { Essential elements of smart } \\
\text { education and their attrib- } \\
\text { utes and roles in smart } \\
\text { education }\end{array}$ & $\begin{array}{l}\text { According to this frame- } \\
\text { work, the essential ele- } \\
\text { ments are teaching pres- } \\
\text { ence, learner presence, and } \\
\text { technological presence. } \\
\text { The goal of the framework } \\
\text { is to identify the roles and } \\
\text { attributes of essential ele- } \\
\text { ments in a smart education } \\
\text { environment }\end{array}$ & Zhu et al. (2016a) \\
\hline $\begin{array}{l}\text { ALECSO \& ITU smart learn- } \\
\text { ing framework }\end{array}$ & $\begin{array}{l}\text { Combining smart learning } \\
\text { program initiatives to form } \\
\text { an international smart } \\
\text { learning framework }\end{array}$ & $\begin{array}{l}\text { The goal of the framework } \\
\text { is to combine various smart } \\
\text { learning program initiatives } \\
\text { to form an international } \\
\text { smart learning effort and } \\
\text { system. Three key dimen- } \\
\text { sions in this framework } \\
\text { are open learning, mobile } \\
\text { technology, and cloud } \\
\text { computing. The program } \\
\text { initiatives are ALECSO Apps } \\
\text { Store, ALECSO Apps Edi- } \\
\text { tor, ALECSO Apps Award, } \\
\text { ALECSO Apps training } \\
\text { programs, ALECSO Cloud } \\
\text { Computing Project, Open } \\
\text { Book Initiative, ALECSO } \\
\text { OER project, ALECSO Mas- } \\
\text { sive Open Online Courses } \\
\text { (MOOCs) Project }\end{array}$ & Jemni and Khribi (2017) \\
\hline $\begin{array}{l}\text { Smart education frame- } \\
\text { work }\end{array}$ & $\begin{array}{l}\text { Identifying the most } \\
\text { suitable learning style via } \\
\text { Al technology in a smart } \\
\text { education environment }\end{array}$ & $\begin{array}{l}\text { The goal of the framework } \\
\text { is to develop a system that } \\
\text { identifies the most suitable } \\
\text { learning style via Al for a } \\
\text { specific student interacting } \\
\text { with a virtual instructor on } \\
\text { the cloud }\end{array}$ & Bajaj and Sharma (2018) \\
\hline $\begin{array}{l}\text { Smart education frame- } \\
\text { work }\end{array}$ & $\begin{array}{l}\text { Generic smart education } \\
\text { design and categorization } \\
\text { of information and com- } \\
\text { munication technologies } \\
\text { based on their role in smart } \\
\text { education. The need for } \\
\text { a coherent combination of } \\
\text { new or improved learning } \\
\text { and teaching methods with } \\
\text { required ICTs }\end{array}$ & $\begin{array}{l}\text { The goal of the framework } \\
\text { is to categorize informa- } \\
\text { tion and communication } \\
\text { technologies based on } \\
\text { their role in smart educa- } \\
\text { tion while stressing the } \\
\text { importance of a coherent } \\
\text { combination of new or } \\
\text { improved learning and } \\
\text { teaching methods with } \\
\text { required ICTs. The smart } \\
\text { education framework in } \\
\text { couple with smart educa- } \\
\text { tion design methodology } \\
\text { helps in designing suitable } \\
\text { smart education systems }\end{array}$ & This study (2021) \\
\hline
\end{tabular}

of the century. However, they did not change the essence of teaching or improve education dramatically yet. Thus, merely having a particular information technology in an educational setting does not create a paradigm shift for education. As a result, new or improved teaching methods are at the center of smart education. 


\section{Smart Education Framework}

New or Improved Learning/Teaching Approaches
The new or improved learning/teaching approaches maximizing the potential of smart education.
The technologies used in the smart education system are chosen in such a way that they support
these approaches.
Essential / Transforming Technologies
These are the essential educational technologies that transform the educational environment into
a smart one.
Enriching Technologies
These are the educational technologies that enrich the educational environment. They support the
goals and increase the effectiveness of the learning/teaching approaches.
Supportive Technologies
The technologies that are not necessarily educational technologies but required for the
information and communication infrastructure of the smart education system.

b

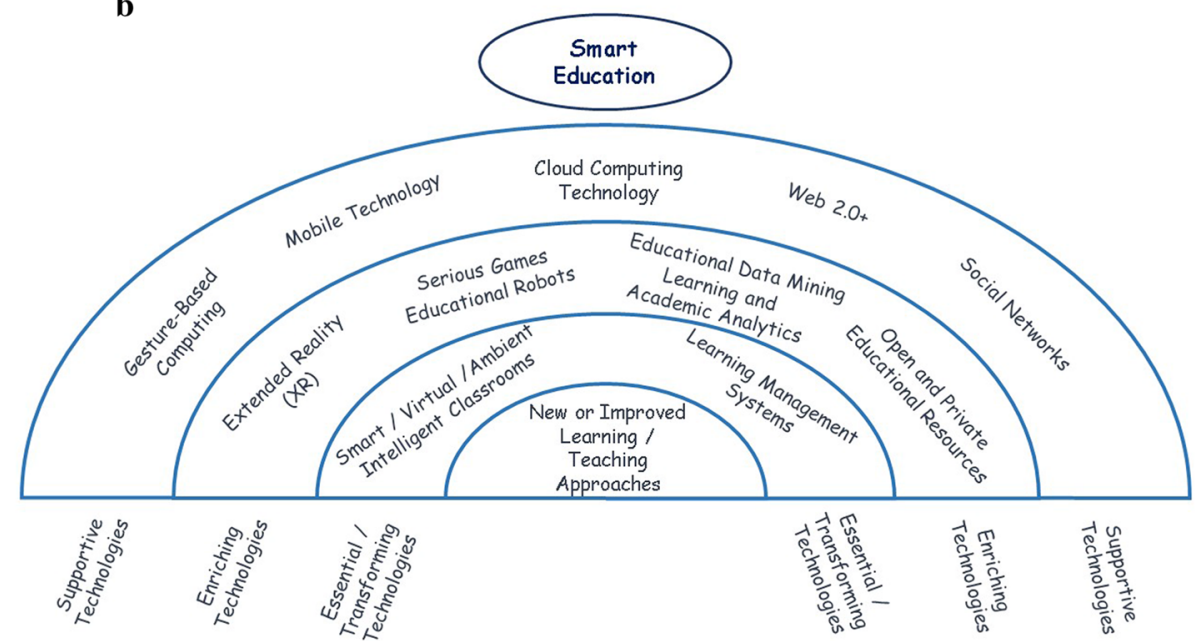

Fig. 2 a Smart education framework layers. b Smart education framework technologies

\section{Essential/transforming technologies (second layer)}

These technologies are essential for smart education and they transform traditional education into smart education combined with new or improved teaching methods. These technologies are learning management systems, smart/ambient intelligent classrooms, and virtual classrooms. Note that we combined smart classrooms with ambient intelligence since they are closely related. Smart classrooms embody the concept of ambient intelligence. Therefore, the terms "smart classrooms" and "ambient intelligent classrooms" may be considered synonyms. These technologies are required for the realization of smart classrooms. They form the necessary infrastructure for the inclusion of enriching and supporting information technologies.

In the figure, we draw a line between smart/ambient intelligent/virtual classrooms and learning management systems. This line also extends to the upper layer of enriching technologies. The line in the upper layer divides the technologies into two. One set of technologies consisting of learning analytics, educational data mining, e-books, 
and interactive books, and academic tubes enrich the learning management systems. The other set of technologies including virtual environments, augmented reality, educational robots, and serious games mainly enrich smart classrooms. With this line, we highlight the upper layer technologies supporting the essential technologies. However, we should keep in mind that technologies are influenced by other technologies, and we cannot draw strict lines between areas. For example, while serious games enrich smart classrooms, they may also be incorporated into learning management systems. Therefore, this line between the layers should be thought of as a guideline indicating which technologies influence which others mainly.

\section{Enriching technologies (third layer)}

The technologies in this layer are the technologies enriching the smart education experience. Incorporating some or all of these technologies into smart education increases the teaching and learning experience. We believe that not all technologies are required for the implementation of smart education in a specific subject or type of education. Depending on the education and training goals, we may employ various technologies in combination and use suitable ones. That is the reason we call this layer as enriching technologies.

\section{Supporting technologies (fourth layer)}

These information technologies are used for many other purposes in addition to education. We may simply call these general-purpose technologies. Therefore, these technologies support the technologies in the below layers.

The layers in smart education are conceptual layers based on their supporting role in the implementation of smart education. The smart education framework does not necessarily show the hierarchy of technology dependence.

This smart education framework is generic. With this framework, we may develop customized frameworks for a specific education goal or subject. For example, we may develop a framework for history teaching. This customized framework may include some of the technologies included in the smart education framework.

The technologies in the smart education framework are not and cannot be exhaustive. New technologies are developed every day. We also find educational use for a specific technology as well. Furthermore, it is hard to draw a boundary line for technology. For example, we did not include holograms as a supporting technology for smart education. The technology for creating holograms is a promising technology that may find extensive use in education. The hologram technology is still quite immature. Also, we may consider holograms as a part of virtual or augmented reality technology.

\section{Smart education design}

We developed a smart education design approach as outlined in Fig. 3. First, we set the objectives for education and training activities. These objectives may be set at different levels such as course objectives or a lecture objective. Then, we choose a suitable pedagogical approach to achieve the objectives. Using the smart education framework, we identify the necessary enriching and supporting technologies. Note that the framework also includes essential and transforming technologies. Since these 


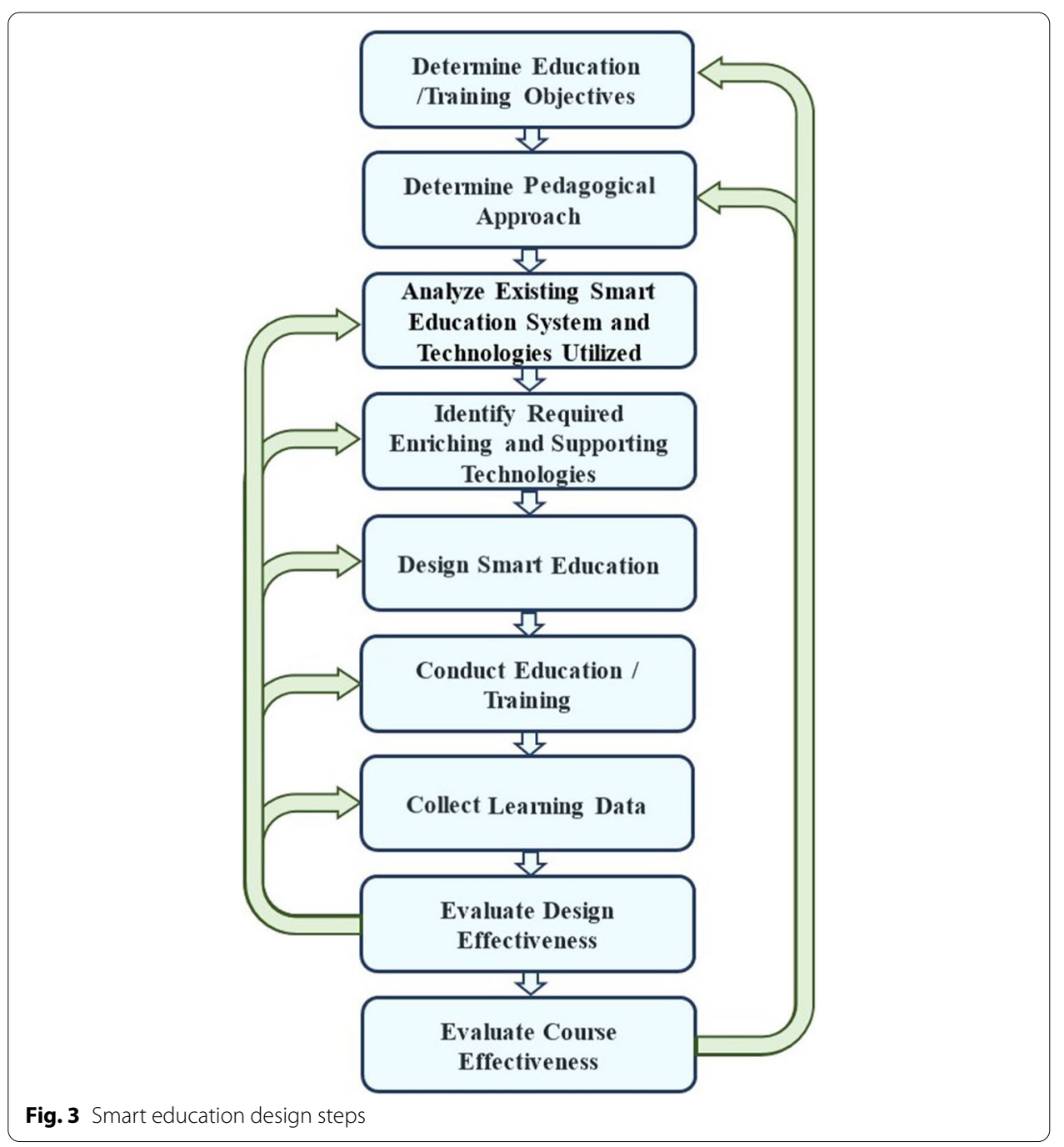

are essential technologies, they are already a part of our design. These essential technologies form the necessary infrastructure for enriching and supporting technologies. Then, we design a smart education that will help us achieve the education/training objectives. Naturally, the next step is to perform the education/training activity. During and after the activity, we collect data to understand the learning effectiveness. Based on the data, we evaluate the smart education design and course/training effectiveness. Our evaluation may shed light on the areas we may need to revise or improve. Therefore, there are feedback loops in the smart education design approach.

Using the smart education design steps and the framework, we may develop smart education implementations for teaching various subjects. Figures 4 and 5 show examples as a result of this process. Next, we detail how the smart education design approach is used to develop various courses/lectures. Note that the examples are developed to show how smart education is designed. Smart education design is likely to require several iterations until it is fully developed to the point that it is effective. Therefore, these examples should be considered as starting points or preliminary designs. 

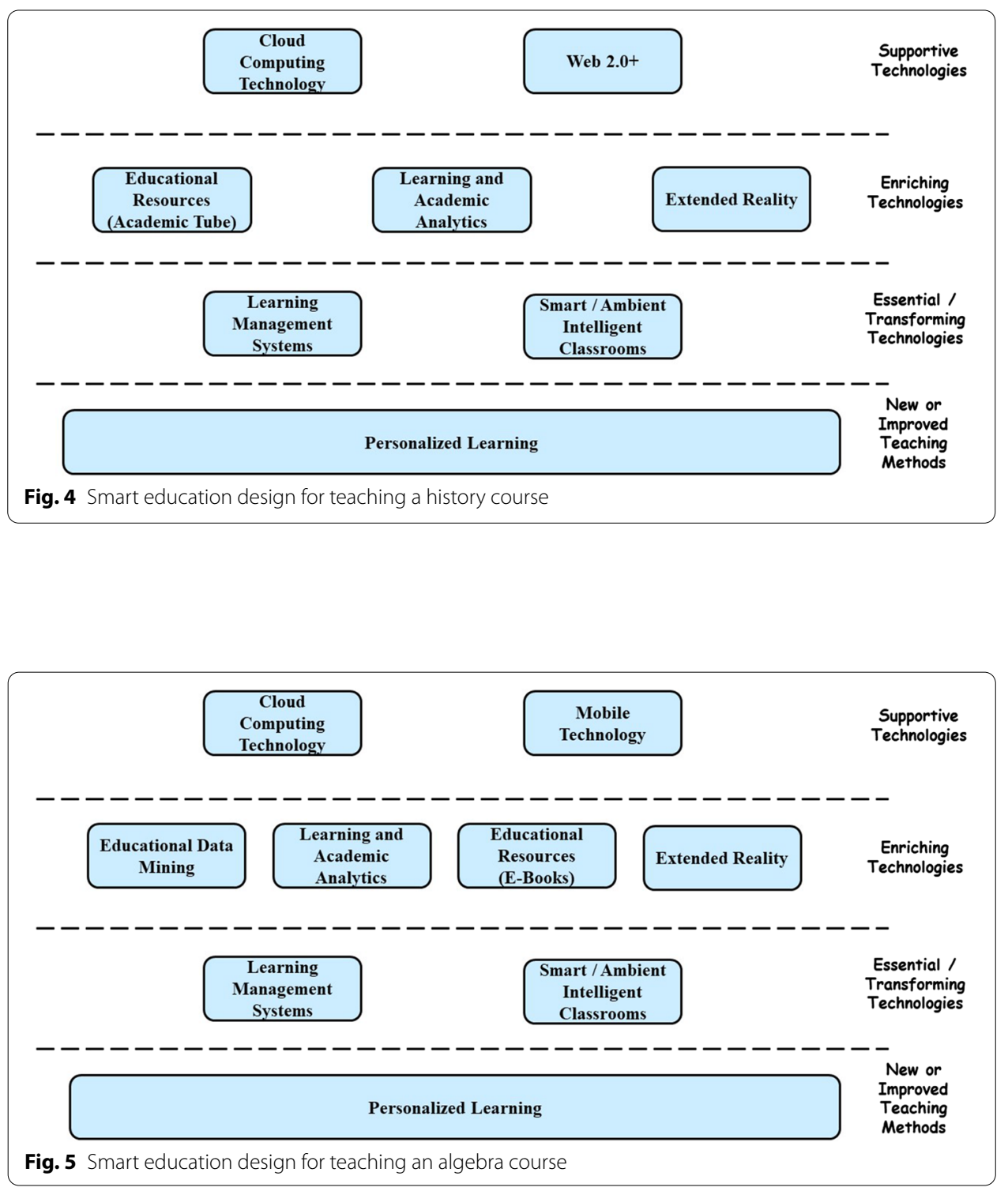

\section{Smart education design example for teaching roman empire era in a history course Determine education/training objectives}

Learn the Roman Empire Era.

Learn why the Roman Empire became one of the most influential empires in world history.

Learn to analyze an era from different points of view based on personal interests.

\section{Determine the pedagogical approach}

We decide to use a personalized learning approach. Rather than trying to teach all the aspects of the Roman Empire in detail, we will let the students focus on the aspects they are interested in. 


\section{Analyze existing smart education system and technologies utilized}

It is also possible that the institution may already have an existing system. When the educational institution would like to improve the existing system, then there is a need to analyze the existing system and the technologies utilized. The analysis will reveal the current effectiveness of the system, its shortcomings, and the required improvements. Based on the analysis results, the smart education system may be modified, upgraded, or redesigned to reach the required education effectiveness. Current system components may be replaced with better alternatives or improved with technological advancements. For the sake of the argument, in this current example, we assumed that the institution acquires a smart education system from scratch. This step applies to institutions that are already using a smart education system and want to improve the system.

\section{Identify required enriching and supporting technologies}

Learning management systems and smart classrooms are considered essential technologies. They are parts of our design. We want to use visual learning aids during the lecture. Thus, we will use a video showing the Roman Empire Era from the academic tube that provides educational videos. The academic tube is hosted in the cloud. Furthermore, we want to show our students a virtual world of the Roman Empire. This virtual world includes parts showing Roman government structure, military structure, justice structure, trading practices, daily life, etc. Therefore, we want to use virtual reality technology. The students may choose to focus on various aspects of the Roman Empire based on their interests. The virtual world allows students to navigate various parts of the Roman Empire Era. Furthermore, we want our students to be analytical in their investigations regarding historical subjects. Therefore, we want them to write a blog based on their analysis of the Roman Empire. A blog is a part of Web 2.0 technologies. The students access their blogs through the learning management system. Also, other students can view and comment on each other's blogs. The teacher follows the students' learning progress via their analysis and discussions on the blogs. The teacher may also lead and support various discussions using the learning management system.

\section{Design smart education}

Once we identified the required technologies, we design our smart education. Figure 4 shows this design. The bottom box displays the learning approach. The other boxes show the technologies and the related systems and the arrows indicate the conceptual interactions. Identifying the required technologies and designing smart education are iterative processes. Until we are satisfied with the design, we iterate these two steps.

In this step, we conduct an educational or training activity.

\section{Collect learning data}

One of the important tasks during the first step is to identify the types of learning data to be collected during the activity. Based on this identification, we collect learning data using the learning management system. We may also get feedback from the students on the effectiveness of the educational activity. 
The goals of the Roman Empire History include learning the Roman Empire Era, why the Roman Empire became one of the most influential empires in world history and analyzing the era from different points of view based on personal interests. When the instructor of the course would like to assess whether the learning outcomes are reached or not, he or she may assign quizzes to students using the learning management system. The system assesses the results of the quizzes and with the help of the learning analytics module, the system recommends students review various educational content using the academic tube or interactive books. Furthermore, the learning analytics module analyzes the students' blogs to provide analyses on the engagement of students, their learning interests, how many times they write to their blogs, which students are more active, how the students interact with each other, etc. This depends on the capabilities of the learning analytics module.

\section{Evaluate design effectiveness}

We evaluate the effectiveness of our smart education design based on our experience during the activity and student feedbacks. In this step, we may also go back to previous steps and revise or improve our educational design.

\section{Evaluate course effectiveness}

This is also an evaluation step. In the previous step, we evaluate the design. In this step, we evaluate whether we are successful in achieving our educational goals. Based on the evaluation, we may repeat the process from the start.

One key aspect of our smart education design approach is the continuous improvement loop. We should always seek ways to improve our educational design. The fastchanging technologies necessitate such an improvement loop.

\section{Smart education design example for teaching algebra}

In this example, we briefly explain how we may design an algebra course using a smart education design approach. We will not go into the details as we did in the previous example. Since some portions of the process are the same. Figure 5 shows the smart education design example for the algebra course.

In this example, our educational goal is to teach algebra in line with the student's progress in learning the subjects. Therefore, we choose adaptive and personalized learning as our main pedagogical approach. We use an interactive book that can be downloaded from the learning management system to the student's mobile tablet. The student's tablet is connected to the learning management system via the smart classroom network infrastructure. The student starts solving algebraic problems, such as functions, following the course syllabus. The learning analytics software module, a part of the learning management system, analyzes whether the student can solve the problem or not, the student's problem-solving technique, the time spent on solving the problem, etc. The learning analytics software module profiles the student's algebraic problem-solving ability and capability. Then, using educational data mining technology, the learning management system downloads the most suitable problem set and order of problems for the student. This problem set and order is identified and optimized by analyzing a great number of students' algebraic problem-solving history. The educational data mining application is 
hosted on the educational cloud. Based on the real-time analysis of a student's problemsolving activity, the system may recommend using the augmented reality system that is loaded with software to help the student understand the problem visually. Note that augmented reality technology is enriching. If we do not have the necessary equipment or the software for the augmented reality system, we may show the student an educational video from the academic tube that is presented on the student's mobile tablet. All this learning activity is monitored with the learning analytics software module. The course teacher helps the students whenever needed. It is possible to argue that the teacher's role is minimized in this smart education design. While it may seem so, we believe the teachers will continue to play a significant role. First of all, this is a complex design requiring several technologies to work in harmony. We may encounter IT-related problems during the course. For example, if the internet connection is lost, then we may not able to download the adaptive problem set from the cloud. Then, the teacher will be the source of the adaptive problem set. Furthermore, there may be some students who learn better with one-to-one human communication. Depending on the availability, accessibility, and effectiveness of the technologies, we may develop other smart education designs. The development of educational design alternatives, course management, and implementation, and on-site observation of the learning activity requires teachers. These and other issues will necessitate the presence of a human teacher at least in the near- and mid-term.

\section{Validation of the framework}

To validate the smart education framework, we investigated the smart education systems (SESs) reported in the literature. For this purpose, we conducted a systematic literature search on the SCOPUS database with the keyword "smart education". The search yielded 353 results. The search was conducted on the title, keywords, and abstracts. The results included book chapters, journal articles, conference proceedings, and some other types of publications. The literature search data is presented in Table 5. Each abstract of the reported study is read and analyzed. After analysis, each study describing a smart education system is carefully investigated. For each SES, the education/learning/teaching method and the information and communication technologies (ICTs) used are identified and mapped to the framework layers and components. An overview of the systematic literature search procedure is presented in Fig. 6.

In the literature, there are various proposals or implementations referred to as smart education systems. However, in some of these studies, the systems referred to as SESs only provide a specific learning function using various ICTs. For example, one such system (Kobayashi et al., 2017) provides the learner with multi-aspect information collected from various Internet resources, such as Wikibooks, Youtube, Twitter, search engines, based on the selected keywords. Essentially, the system is a smart multi-aspect educational content collector. There are also various studies focusing on computerengineering-related issues rather than educational issues. For example, Shapsough and Zualkernan (2020) developed an IoT-based system for ubiquitous context-aware learning. In the study, they discussed the Internet of Things (IoT) system architecture, suitable networking protocols, and networking performance of an example implementation. They did not focus on how the proposed system contributes to education. Therefore, in 
Table 5 Literature search data

\begin{tabular}{ll}
\hline Literature search & \\
\hline Search keyword & "Smart education" \\
Search goal & To identify smart education systems \\
Number of results & 353 \\
Publication date range & $2003-2021$ \\
Type of publications & \# Conference Papers $=208$ \\
& \# Journal Articles $=105$ \\
& \# Book Chapter $=15$ \\
& \# Others $=25$ \\
Date of publications & $2021=1 \quad 2017=43$ \\
& $2020=52 \quad 2016=37$ \\
& $2019=80 \quad 2015=25$ \\
Predominant source & $2018=77 \quad 2014-2003=37$ \\
& $2016-2020$ international KES \\
Number of identified smart education systems & conference on smart education and \\
\hline
\end{tabular}

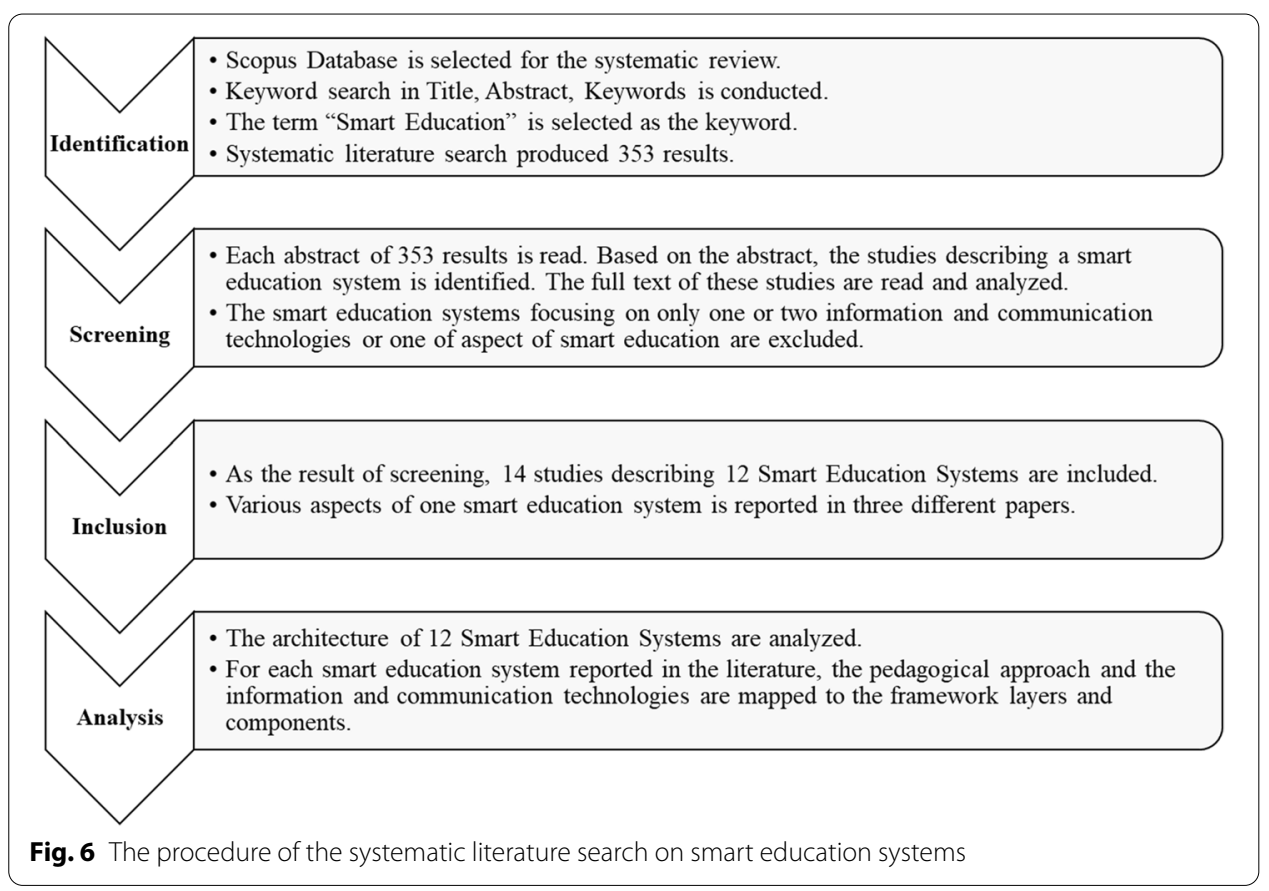

our literature search, the SESs selected are the studies focusing on how the proposed system contributes to education rather than studies only discussing IT-related issues or one limited aspect of smart education.

During the screening phase of the literature search, we identified that half of the studies only use the "smart education" phrase for enriching the argument of their study. These studies mostly focus on achieving smartness in the context of Industry 4.0, smart cities, or smart campuses. Smart campus-related studies mostly discuss issues other than education such as incorporating biometrics to increase security on the campus 
etc. One-third of the studies focus on the organizational, economic, or social issues of smart education. Among the rest, several abstracts are related to the contents of conference proceedings including smart education studies. Therefore, only a handful of studies focus on the development of smart education systems or the use of particular information technology in the educational context. As a result, even though we aimed at including as many studies as possible for analysis, there were only 12 systems that can be classified as smart education systems comprising a coherent use of pedagogical approaches and ITs. The studies focusing on only one aspect of smart education mostly discussed learning analytics and personalized learning. Note that our goal is not a systematic review of smart education, but to identify SESs among these studies. Therefore, we only investigate and report the SES-related studies. Tables 6 and 7 present the identified Smart Education Systems as a result of this systematic literature search.

There are several findings when SESs included in our analysis are examined. The first finding is that the smart education framework is able to describe the smart education systems developed or proposed in the literature. All the systems listed in Table 2 have an important characteristic: These systems are developed based on a specific (or a specific set of) teaching or learning approaches. Personalized, Individualized, Adaptive, Interactive, Ubiquitous, Collaborative, Flipped, Blended, Case-based, and Challenge-based learning are the learning approaches that form the basis for the smart education systems listed in Table 2. Note that, in our framework, the learning and teaching approach is the core layer. The identified SESs include at least one type of IT from each layer in the smart education framework. So, we can say that the layered architecture of the smart education framework is a suitable approach for designing SESs. Another finding is that almost all of the SESs utilize a type of software providing certain functionalities of learning management systems. Basically, there is software that brings ICT components together and manages the learning/teaching-related tasks and other types of tasks in the system. Three of the SESs specifically state the use of smart classrooms. However, for others, we cannot be sure about the educational environment since in those studies the educational environment is not specifically spelled out. Furthermore, since most of the systems are currently at the architectural design phase, we believe the educational environment will be specified in the implementation phases of the system developments. Ambient intelligent classrooms, smart classrooms, virtual classrooms, interactive books, e-books, learning analytics, academic tubes, virtual reality, augmented reality, gesturebased computing, cloud computing, mobile devices, web 2.0, and social networks are information technologies used in SESs. Learning analytics, e-books, mobile devices, and cloud computing are commonly used in current SES designs or implementations. We did not find examples of educational robot use, serious games, and educational data mining in the identified systems.

Based on the analysis of the findings, we determine that the smart education framework has the capability to serve as a guide for smart education system designs. Note that the smart education framework does not necessitate the use of all information technologies in a single smart education system. The framework aims at building a base for the suitable use of the pedagogical approach and a coherent set of information technologies to reach a learning outcome. This is in line with our definition of smart education. 
Table 6 Smart education system descriptions

\begin{tabular}{|c|c|c|c|}
\hline References & $\begin{array}{l}\text { Implementation/ } \\
\text { prototype/architectural } \\
\text { design/framework }\end{array}$ & $\begin{array}{l}\text { System/architecture } \\
\text { name }\end{array}$ & $\begin{array}{l}\text { System implementation/ } \\
\text { prototype/architectural } \\
\text { design/architectural } \\
\text { framework description }\end{array}$ \\
\hline Leonidis et al. (2010) & Architectural design & ClassMATE & $\begin{array}{l}\text { The ClassMATE design } \\
\text { builds upon the Ambi- } \\
\text { ent Intelligence (Aml) } \\
\text { paradigm. Its major } \\
\text { components are ClassMATE } \\
\text { core and API library. The } \\
\text { core incorporates five major } \\
\text { components: Security } \\
\text { service, User Profile, Device } \\
\text { Manager, Data Space, and } \\
\text { Context Manager. The API } \\
\text { library provides the edu- } \\
\text { cational application library } \\
\text { infrastructure. ClassMATE } \\
\text { relies on a generic services } \\
\text { interoperability platform, } \\
\text { named FAMINE (FORTH's } \\
\text { AMI Network Environment). } \\
\text { This platform provides the } \\
\text { necessary intercommunica- } \\
\text { tion between services. The } \\
\text { context manager and the } \\
\text { data space components } \\
\text { provide the necessary } \\
\text { context-aware educational } \\
\text { activity management and } \\
\text { content provision. The } \\
\text { ClassMATE core provides } \\
\text { Learning Management Sys- } \\
\text { tem related functionalities } \\
\text { among others. The design } \\
\text { is based on the Aml class- } \\
\text { room concept that is real- } \\
\text { ized with a device manager } \\
\text { service. Context Manager } \\
\text { and Data Space provide } \\
\text { learning analytics services } \\
\text { and interactive educational } \\
\text { content management. The } \\
\text { FAMINE platform provides } \\
\text { the necessary infrastruc- } \\
\text { ture for ubiquitous cloud } \\
\text { services }\end{array}$ \\
\hline
\end{tabular}


Table 6 (continued)

\begin{tabular}{|c|c|c|c|}
\hline References & $\begin{array}{l}\text { Implementation/ } \\
\text { prototype/architectural } \\
\text { design/framework }\end{array}$ & $\begin{array}{l}\text { System/architecture } \\
\text { name }\end{array}$ & $\begin{array}{l}\text { System implementation/ } \\
\text { prototype/architectural } \\
\text { design/architectural } \\
\text { framework description }\end{array}$ \\
\hline Obasa et al. (2011) & Architectural design & $\begin{array}{l}\text { Integrated virtual class- } \\
\text { room system }\end{array}$ & $\begin{array}{l}\text { The proposed system } \\
\text { architecture builds upon } \\
\text { the notion of collaborative } \\
\text { learning via incorporating } \\
\text { asynchronous and synchro- } \\
\text { nous learning platforms. } \\
\text { The system architecture } \\
\text { consists of four interrelated } \\
\text { modules, namely, Applica- } \\
\text { tion tiers, Application } \\
\text { objects, Data Process- } \\
\text { ing module, and Course } \\
\text { module in a multi-tier } \\
\text { network infrastructure. The } \\
\text { application tier provides the } \\
\text { network infrastructure. The } \\
\text { application objects provide } \\
\text { the software application } \\
\text { infrastructure. The data pro- } \\
\text { cessing module provides } \\
\text { the data flow infrastructure. } \\
\text { The course module pro- } \\
\text { vides the learning content- } \\
\text { related management. The } \\
\text { application functional } \\
\text { modules include the user } \\
\text { registration module, course } \\
\text { registration module, assign- } \\
\text { ment module, chat module, } \\
\text { glossary module, Elluminate } \\
\text { module, lessons module, } \\
\text { wiki, and workshop module } \\
\text { The proposed system has } \\
\text { learning management sys- } \\
\text { tem functionalities, a net- } \\
\text { worked virtual classroom } \\
\text { environment, educational } \\
\text { resources via application } \\
\text { modules, interactive web } \\
\text { services modules (such as } \\
\text { a forum, wiki, etc.) using } \\
\text { Web } 2.0+\text { technologies }\end{array}$ \\
\hline
\end{tabular}


Table 6 (continued)

\begin{tabular}{|c|c|c|c|}
\hline References & $\begin{array}{l}\text { Implementation/ } \\
\text { prototype/architectural } \\
\text { design/framework }\end{array}$ & $\begin{array}{l}\text { System/architecture } \\
\text { name }\end{array}$ & $\begin{array}{l}\text { System implementation/ } \\
\text { prototype/architectural } \\
\text { design/architectural } \\
\text { framework description }\end{array}$ \\
\hline Hirsch et al. (2012) & Design & $\begin{array}{l}\text { Next generation learning } \\
\text { environment (NGLE) }\end{array}$ & $\begin{array}{l}\text { The goal of the Next Gen- } \\
\text { eration Learning Environ- } \\
\text { ment (NGLE) is to provide } \\
\text { a learning platform that } \\
\text { allows the integration of } \\
\text { heterogeneous systems. } \\
\text { The learning platform } \\
\text { provides data management } \\
\text { student profile manage- } \\
\text { ment, learning and aca- } \\
\text { demic analytics, the group- } \\
\text { ing of users for educational } \\
\text { purposes. The design is } \\
\text { envisioned to incorporate } \\
\text { more services as they are } \\
\text { available. The learning } \\
\text { platform is envisioned to } \\
\text { acquire content or services } \\
\text { from Banner or Moodle. In } \\
\text { addition, the platform inte- } \\
\text { grates with various systems } \\
\text { such as social network for } \\
\text { learning (ELSE), collabora- } \\
\text { tive learning environment } \\
\text { (CLE), student grouping } \\
\text { system to support collabo- } \\
\text { rative learning, document } \\
\text { classification for recommen- } \\
\text { dation to support smart } \\
\text { content provision, student } \\
\text { care management (SCM) to } \\
\text { support a number of learn- } \\
\text { ing analytics functionalities. } \\
\text { With a focus on collabora- } \\
\text { tive learning, NGLE provides } \\
\text { learning management, } \\
\text { social networking, and } \\
\text { learning analytics function- } \\
\text { alities }\end{array}$ \\
\hline
\end{tabular}


Table 6 (continued)

\begin{tabular}{|c|c|c|c|}
\hline References & $\begin{array}{l}\text { Implementation/ } \\
\text { prototype/architectural } \\
\text { design/framework }\end{array}$ & $\begin{array}{l}\text { System/architecture } \\
\text { name }\end{array}$ & $\begin{array}{l}\text { System implementation/ } \\
\text { prototype/architectural } \\
\text { design/architectural } \\
\text { framework description }\end{array}$ \\
\hline Jo et al., $(2012,2014,2016)$ & $\begin{array}{l}\text { Prototype and partial } \\
\text { system implementation }\end{array}$ & $\begin{array}{l}\text { Structured plug-in } \\
\text { integrated teaching and } \\
\text { learning (ITLA) system }\end{array}$ & $\begin{array}{l}\text { The system consists of a } \\
\text { Smart Content Service } \\
\text { System and School and } \\
\text { Home Learning System. } \\
\text { The system is designed to } \\
\text { provide services that enable } \\
\text { smart learning, smart } \\
\text { teaching, smart creating, } \\
\text { and smart assessing. The } \\
\text { Smart Content Service } \\
\text { System is composed of } \\
\text { tools and services that are } \\
\text { connected to a content } \\
\text { management system (CMS) } \\
\text { It includes a smart contents } \\
\text { creation tool, content auto- } \\
\text { translation service, content } \\
\text { auto-transfer tool. The smart } \\
\text { school and home learning } \\
\text { system include a learning } \\
\text { management system con- } \\
\text { nected with a smart learn- } \\
\text { ing tool, smart class, and } \\
\text { personalized learning assis- } \\
\text { tance tool. The smart learn- } \\
\text { ing tools in couple with } \\
\text { other tools provide learning } \\
\text { and academic analytics } \\
\text { functionalities. The smart } \\
\text { class is supported with } \\
\text { smart devices, desktops, } \\
\text { and smartboards. The CMS } \\
\text { and LMS are supported } \\
\text { with a contents repository } \\
\text { system. As a whole, based } \\
\text { on personalized learning, } \\
\text { this smart education system } \\
\text { offers LMS, a smart class- } \\
\text { room environment, learning } \\
\text { analytics functionalities, } \\
\text { educational resources built } \\
\text { upon mobile and cloud } \\
\text { computing technology }\end{array}$ \\
\hline
\end{tabular}


Table 6 (continued)

\begin{tabular}{|c|c|c|c|}
\hline References & $\begin{array}{l}\text { Implementation/ } \\
\text { prototype/architectural } \\
\text { design/framework }\end{array}$ & $\begin{array}{l}\text { System/architecture } \\
\text { name }\end{array}$ & $\begin{array}{l}\text { System implementation/ } \\
\text { prototype/architectural } \\
\text { design/architectural } \\
\text { framework description }\end{array}$ \\
\hline Jeong et al. (2013) & Architectural design & $\begin{array}{l}\text { Content oriented smart } \\
\text { education system }\end{array}$ & $\begin{array}{l}\text { The proposed system is } \\
\text { a cloud-based system in } \\
\text { which the educational } \\
\text { resources content is stored } \\
\text { on the cloud. The system } \\
\text { utilizes an authoring tool for } \\
\text { creating smart media con- } \\
\text { tent including texts, images } \\
\text { videos, 3D, AR, VR objects. } \\
\text { Cloud-based smart media } \\
\text { services, content viewer } \\
\text { for displaying smart media } \\
\text { content, inference engine } \\
\text { for providing customized } \\
\text { learning content, security } \\
\text { system are applications that } \\
\text { support the systems The } \\
\text { content provider (instruc- } \\
\text { tor) creates educational } \\
\text { content, and consum- } \\
\text { ers (learners) consumes } \\
\text { content that is stored on } \\
\text { the cloud and accessible via } \\
\text { devices including mobiles. } \\
\text { The system supports } \\
\text { both open and private } \\
\text { educational content. The } \\
\text { inference engine provides } \\
\text { students with personal- } \\
\text { ized content by analyzing } \\
\text { preferences, learning styles, } \\
\text { content usage, and interac- } \\
\text { tion patterns. The platform } \\
\text { for cloud-based educationa } \\
\text { smart media services with } \\
\text { support from other tools } \\
\text { provides LMS functional- } \\
\text { ity, educational resources, } \\
\text { and ubiquitous access via } \\
\text { any device. The inference } \\
\text { engine provides learning } \\
\text { analytics functionality }\end{array}$ \\
\hline
\end{tabular}


Table 6 (continued)

\begin{tabular}{|c|c|c|c|}
\hline References & $\begin{array}{l}\text { Implementation/ } \\
\text { prototype/architectural } \\
\text { design/framework }\end{array}$ & $\begin{array}{l}\text { System/architecture } \\
\text { name }\end{array}$ & $\begin{array}{l}\text { System implementation/ } \\
\text { prototype/architectural } \\
\text { design/architectural } \\
\text { framework description }\end{array}$ \\
\hline Hwang (2014) & Framework & $\begin{array}{l}\text { Context-aware ubiquitous } \\
\text { learning environment }\end{array}$ & $\begin{array}{l}\text { The framework of a smart } \\
\text { learning environment } \\
\text { consists of the following } \\
\text { modules: learningsta- } \\
\text { tus detecting, learning } \\
\text { performance evaluation, } \\
\text { adaptive learning task, } \\
\text { adaptive learning content, } \\
\text { personal learning support, } \\
\text { databases for learner } \\
\text { profiles, inference engine, } \\
\text { and knowledge base. The } \\
\text { system based on this frame- } \\
\text { work is envisioned to work } \\
\text { on a wireless communica- } \\
\text { tion network and to provide } \\
\text { a user interface to students } \\
\text { for smart learning. Mobile } \\
\text { technology supported } \\
\text { with a wireless network will } \\
\text { enable ubiquitous access } \\
\text { to users. This framework } \\
\text { benefits from learning } \\
\text { analytics functionalities } \\
\text { via its modules. To realize } \\
\text { this framework a learning } \\
\text { management system will } \\
\text { be required }\end{array}$ \\
\hline
\end{tabular}


Table 6 (continued)

\begin{tabular}{|c|c|c|c|}
\hline References & $\begin{array}{l}\text { Implementation/ } \\
\text { prototype/architectural } \\
\text { design/framework }\end{array}$ & $\begin{array}{l}\text { System/architecture } \\
\text { name }\end{array}$ & $\begin{array}{l}\text { System implementation/ } \\
\text { prototype/architectural } \\
\text { design/architectural } \\
\text { framework description }\end{array}$ \\
\hline Ali et al. (2017) & Architectural design & $\begin{array}{l}\text { loTFLiP: IoT-based flipped } \\
\text { learning platform }\end{array}$ & $\begin{array}{l}\text { The proposed architecture } \\
\text { is designed for flipped and } \\
\text { case-based learning (CBL) } \\
\text { for medical education. The } \\
\text { platform architecture has } \\
\text { business, application and } \\
\text { service, presentation, and } \\
\text { cloud security layers on the } \\
\text { cloud. On the client-side, } \\
\text { access technologies, local } \\
\text { security, data aggregation } \\
\text { and preprocessing, and } \\
\text { data perception layers. } \\
\text { The architecture proposes } \\
\text { an interactive case-based } \\
\text { flip learning tool (ICBFLT) } \\
\text { that facilitates the learning } \\
\text { activity between students } \\
\text { and medical experts. The } \\
\text { platform supports medical } \\
\text { case data collection via } \\
\text { loT devices, data creation, } \\
\text { case formulation, case } \\
\text { evaluation, case feedback, } \\
\text { and storage of medical } \\
\text { knowledge. The business, } \\
\text { application, and service } \\
\text { layers in combination with } \\
\text { the security layer provide } \\
\text { various LMS functionalities. } \\
\text { ICBFLT provides medical } \\
\text { educational content with } \\
\text { the help of a CBL Case } \\
\text { Repository. loT devices sup- } \\
\text { ported by mobile technol- } \\
\text { ogy collect medical data for } \\
\text { case creation }\end{array}$ \\
\hline
\end{tabular}


Table 6 (continued)

\begin{tabular}{|c|c|c|c|}
\hline References & $\begin{array}{l}\text { Implementation/ } \\
\text { prototype/architectural } \\
\text { design/framework }\end{array}$ & $\begin{array}{l}\text { System/architecture } \\
\text { name }\end{array}$ & $\begin{array}{l}\text { System implementation/ } \\
\text { prototype/architectural } \\
\text { design/architectural } \\
\text { framework description }\end{array}$ \\
\hline El Janati et al. (2018) & Architectural design & $\begin{array}{l}\text { Adaptive learning system } \\
\text { based on dynamic adap- } \\
\text { tive hypermedia system }\end{array}$ & $\begin{array}{l}\text { The proposed approach } \\
\text { aims at providing adaptive } \\
\text { educational content based } \\
\text { on learners' preferences and } \\
\text { the disability of learners. } \\
\text { The proposed approach } \\
\text { utilizes a Dynamic Adaptive } \\
\text { Hypermedia System (DAHS) } \\
\text { The adaptive learning } \\
\text { system (ALS) architecture } \\
\text { includes a learner detector } \\
\text { engine, learner model } \\
\text { engine, transcoding engine, } \\
\text { domain model, adaptation } \\
\text { presentation engine. In this } \\
\text { proposal, the system adapts } \\
\text { the educational content } \\
\text { for learners suffering from } \\
\text { visual and auditory limita- } \\
\text { tions. Various mechanisms } \\
\text { such as text-to-speech, } \\
\text { speech-to-text are used to } \\
\text { adapt educational content } \\
\text { to learners. The learner } \\
\text { detector combined with } \\
\text { the learner model provides } \\
\text { learning analytics functions. } \\
\text { The proposed architec- } \\
\text { ture provides educational } \\
\text { content (text, image, audio, } \\
\text { and video) via adaptive web } \\
\text { pages }\end{array}$ \\
\hline Bajaj and Sharma (2018) & Framework & $\begin{array}{l}\text { Smart education with } \\
\text { artificial intelligence } \\
\text { based determination of } \\
\text { learning styles }\end{array}$ & $\begin{array}{l}\text { The goal of the framework } \\
\text { is to develop a system that } \\
\text { identifies the most suitable } \\
\text { learning style via Al for a } \\
\text { specific student interacting } \\
\text { with a virtual instructor on } \\
\text { the cloud. In this frame- } \\
\text { work, the software tool } \\
\text { utilizes artificial intelligence } \\
\text { to analyze the students' } \\
\text { learning styles. Then the } \\
\text { learning styles are used } \\
\text { to generate personalized } \\
\text { content and personalized } \\
\text { learning paths. The interac- } \\
\text { tion with the virtual teacher } \\
\text { is enabled with cloud } \\
\text { computing technology. } \\
\text { The software tool provides } \\
\text { LMS and learning analytics } \\
\text { functionality }\end{array}$ \\
\hline
\end{tabular}


Table 6 (continued)

\begin{tabular}{|c|c|c|c|}
\hline References & $\begin{array}{l}\text { Implementation/ } \\
\text { prototype/architectural } \\
\text { design/framework }\end{array}$ & $\begin{array}{l}\text { System/architecture } \\
\text { name }\end{array}$ & $\begin{array}{l}\text { System implementation/ } \\
\text { prototype/architectural } \\
\text { design/architectural } \\
\text { framework description }\end{array}$ \\
\hline Hartono et al. (2018) & Architectural design & $\begin{array}{l}\text { Smart hybrid learning } \\
\text { system }\end{array}$ & $\begin{array}{l}\text { Smart Hybrid Learning } \\
\text { System (SHLS) is based } \\
\text { on Smart Hybrid Learning } \\
\text { Method (SHLM) supporting } \\
\text { flipped classrooms com- } \\
\text { bined with Challenge Based } \\
\text { Learning and Case-Based } \\
\text { Learning. In SHLM, students } \\
\text { learn in and out of class. In } \\
\text { out-of-class learning, the } \\
\text { students will have access to } \\
\text { not only teachers but also } \\
\text { industry and community } \\
\text { partners. The educational } \\
\text { resources are obtained from } \\
\text { platforms providing MOOC } \\
\text { that supports quizzes and } \\
\text { tests. SHLS is envisioned } \\
\text { to integrate with smart } \\
\text { learning, social media, } \\
\text { MOOC out-of-class tech- } \\
\text { nologies. Challenge-based } \\
\text { learning system (CBLS) } \\
\text { and case-based learning } \\
\text { (CBL) system are in-class } \\
\text { technologies integrated } \\
\text { with SHLS. Furthermore, the } \\
\text { SHLS supports interaction } \\
\text { with industries, govern- } \\
\text { ment, communities, and } \\
\text { experts while creating a } \\
\text { smart learning environ- } \\
\text { ment. The proposed system } \\
\text { framework has } 3 \text { layers } \\
\text { such as view layer, domain } \\
\text { layer, data access layer. } \\
\text { The view layer provides } \\
\text { the user interface for } \\
\text { SHLS. In the domain layer, } \\
\text { there are smart learning } \\
\text { system, smart conference } \\
\text { layer, forum discussion } \\
\text { layer, MOOC layer, Social } \\
\text { Media Layer, CBLS layer, } \\
\text { CBL system layer. The data } \\
\text { access layer provides the } \\
\text { database server acting as } \\
\text { a content repository. The } \\
\text { SHLS provides LMS, edu- } \\
\text { cational resource access, } \\
\text { social media access, and } \\
\text { advanced web functionali- } \\
\text { ties }\end{array}$ \\
\hline
\end{tabular}


Table 6 (continued)

\begin{tabular}{|c|c|c|c|}
\hline References & $\begin{array}{l}\text { Implementation/ } \\
\text { prototype/architectural } \\
\text { design/framework }\end{array}$ & $\begin{array}{l}\text { System/architecture } \\
\text { name }\end{array}$ & $\begin{array}{l}\text { System implementation/ } \\
\text { prototype/architectural } \\
\text { design/architectural } \\
\text { framework description }\end{array}$ \\
\hline Kim et al. (2018) & Architectural design & $\begin{array}{l}\text { Emotionally aware Al } \\
\text { smart classroom }\end{array}$ & $\begin{array}{l}\text { The goal of the Emotionally } \\
\text { Aware Al Smart Classroom } \\
\text { is to create an educational } \\
\text { environment in which } \\
\text { the presenter is provided } \\
\text { feedback on the emotional } \\
\text { responses of audiences. } \\
\text { Based on this feedback, } \\
\text { the presenter will adapt } \\
\text { their body language, voice } \\
\text { intonation, and other } \\
\text { non-verbal behavior to } \\
\text { provide a more effective } \\
\text { and emotionally intelligent } \\
\text { presentation aiming for } \\
\text { better learning. The system } \\
\text { captures non-verbal cues } \\
\text { including facial expressions, } \\
\text { body movements, speech } \\
\text { prosody, etc. Then these } \\
\text { cues are analyzed via artifi- } \\
\text { cial intelligence technology } \\
\text { Based on crowd scoring, the } \\
\text { system analyzes listeners via } \\
\text { Al technology. The machine } \\
\text { intelligence component } \\
\text { of the system sends data } \\
\text { to the feedback decision } \\
\text { component that provides } \\
\text { feedback to the presenter } \\
\text { via haptic glove or some } \\
\text { other visual aid. The system } \\
\text { is envisioned to work in a } \\
\text { cloud environment as well. } \\
\text { This system supports the } \\
\text { notion of adaptive tutoring } \\
\text { with help of academic } \\
\text { analytics based on machine } \\
\text { intelligence. Gesture-based } \\
\text { computing in combination } \\
\text { with ambient intelligent/ } \\
\text { smart classroom and relateo } \\
\text { technologies are used to } \\
\text { recognize and analyze } \\
\text { the presenter's verbal and } \\
\text { non-verbal cues }\end{array}$ \\
\hline
\end{tabular}


Table 6 (continued)

\begin{tabular}{|c|c|c|c|}
\hline References & $\begin{array}{l}\text { Implementation/ } \\
\text { prototype/architectural } \\
\text { design/framework }\end{array}$ & $\begin{array}{l}\text { System/architecture } \\
\text { name }\end{array}$ & $\begin{array}{l}\text { System implementation/ } \\
\text { prototype/architectural } \\
\text { design/architectural } \\
\text { framework description }\end{array}$ \\
\hline Lisitsyna et al. (2020) & Prototype & $\begin{array}{l}\text { Basic online course- } \\
\text { remote laboratory control } \\
\text { protocol (RLCP)-com- } \\
\text { patible virtual laboratory } \\
\text { technology }\end{array}$ & $\begin{array}{l}\text { The goal of this approach } \\
\text { is to increase the learn- } \\
\text { ing effectiveness utilizing } \\
\text { blended learning technol- } \\
\text { ogy with the use of a basic } \\
\text { online course. Remote } \\
\text { Laboratory Control Protocol } \\
\text { (RLCP)-Compatible Virtual } \\
\text { Laboratory Technology for } \\
\text { a MOOC was modified and } \\
\text { improved. The system is } \\
\text { supported by virtual stands } \\
\text { that allow students to solve } \\
\text { practical exercises indi- } \\
\text { vidually. After finishing the } \\
\text { exercise, the student sends } \\
\text { the results to the RLCP } \\
\text { server to get evaluation } \\
\text { results. Virtual laboratory } \\
\text { uses special algorithms to } \\
\text { construct efficient learning } \\
\text { paths. The system provides } \\
\text { basic LMS and learning } \\
\text { analytics functionalities. } \\
\text { Virtual stands and virtual } \\
\text { laboratories are realized } \\
\text { with web technologies }\end{array}$ \\
\hline
\end{tabular}

A summary of the findings are presented below:

- The smart education framework (SEF) has the capability to describe all the identified Smart Education Systems (SESs).

- The earliest SESs identified is reported in 2010. The latest one is reported in 2020.

- Most of the SESs are architectural designs at this point. Only a few SESs are partial or prototype implementations.

- All identified SESs are based on a learning/teaching approach. Personalized, Individualized, Adaptive, Interactive, Ubiquitous, Collaborative, Flipped, Blended, Case-based, and Challenge-based learning are among these approaches.

- Almost all identified SESs utilize a type of software providing various features of learning management systems.

- The identified SESs include at least one type of IT from each layer.

- Ambient intelligent classrooms, smart classrooms, virtual classrooms, interactive books, e-books, learning analytics, academic tubes, virtual reality, augmented reality, gesture-based computing, cloud computing, mobile devices, web 2.0, and social networks are information technologies used in SESs.

- Learning analytics, e-books, mobile devices, and cloud computing are commonly used in current SES proposals or implementations.

- We did not find examples of educational robot use, serious games, and educational data mining in the identified systems. 

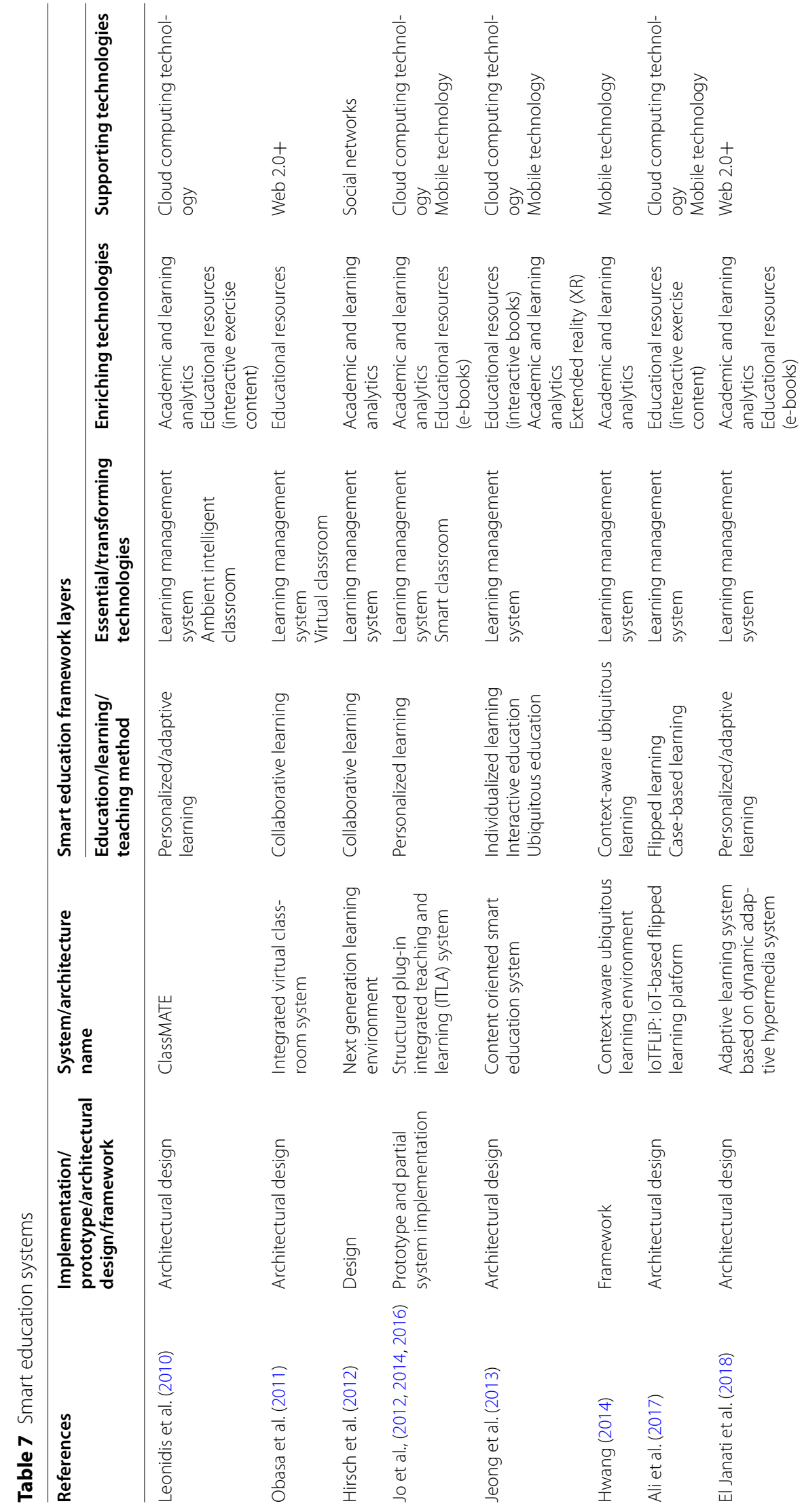


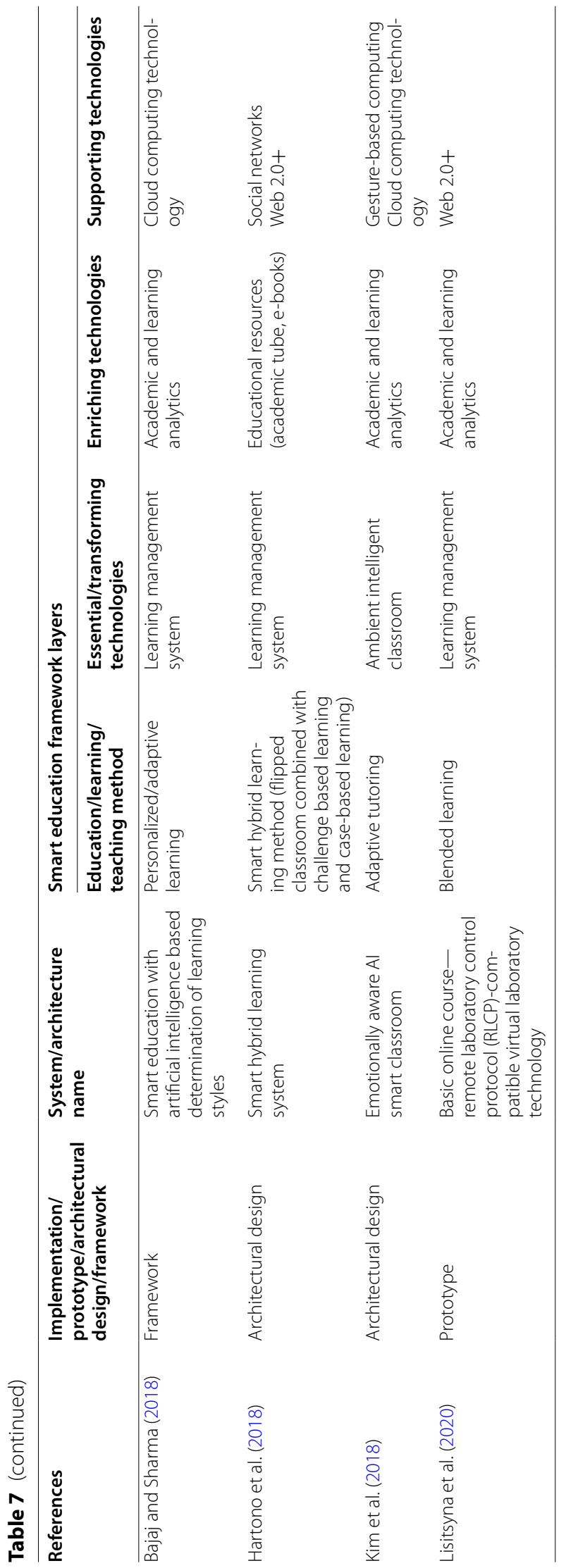




\section{Discussions}

According to various scholars including us, the term "smart" inherently encompasses the use of various intelligence technologies. What makes a system "smart" is the use of a certain level of AI technologies in the system. The level is dependent on the need, available AI technologies, and budgetary concerns. As a result, a smart education system is inherently expected to create an intelligent environment for education and training activities.

Note that the framework is conceptually layered to highlight the contributing roles of various technologies in smart education. These are technologies and in an actual system implementation, the software and hardware components used may utilize various technologies at the same time. For example, a learning management system may already be implemented with learning analytics, open or private educational contents such as e-books or interactive books, gesture-based computing for disabled users, etc. These technologies may be implemented as software modules of the learning management system and the interaction between these modules will not necessarily be linear. In fact, the interaction among modules or components will be complex and non-linear to meet the system goals and requirements. Consider the following example implementation of a smart education system based on the Service-Oriented Architecture (SOA). While the SOA middleware software handles the communication between services offered with smart education modules, the system controller module handles the interaction required to achieve certain system tasks. As a result, while the smart education framework depicts the technologies in a layered fashion to ease the understanding of technology roles within the educational context, in actual system implementations these technologies form the basis for designing and implementing necessary education system components and modules with nonlinear interactions.

In the previous examples depicted in Figs. 4 and 5, we highlighted technologies used in specific course design examples. Note that these are technologies, rather than actual systems or system components. In actual smart education system implementations, these technologies will be realized with software and hardware components. The functionalities provided with these technologies may be allocated to one or more components. Figure 7 shows an example of smart education system implementation based on service-oriented architecture (SOA). In this example, the software components providing services communicate with each other utilizing an SOA middleware. To accomplish a smart educational task, complex interactions among a

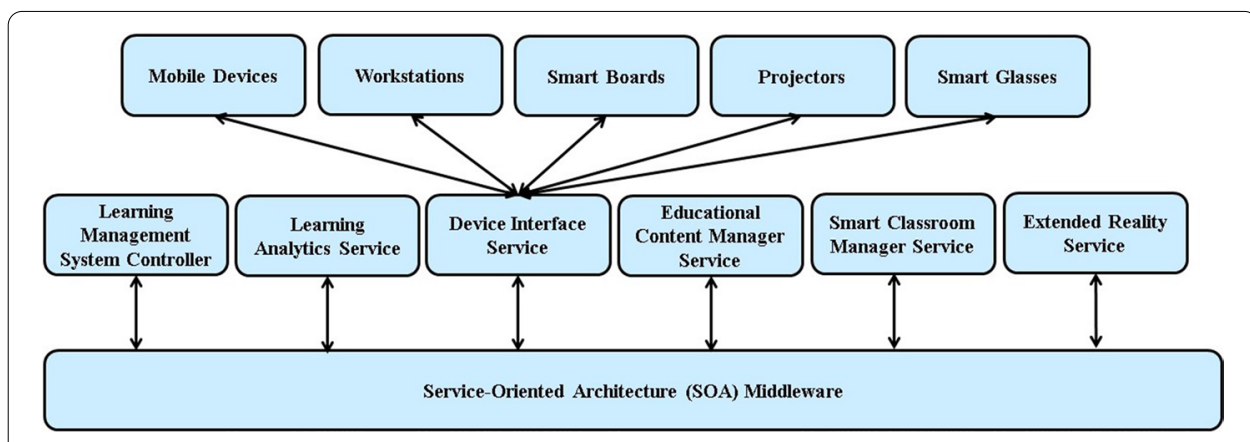

Fig. 7 An Example smart education system implementation based on service-oriented architecture 
number of components may be required depending on the design. Therefore, while the conceptual smart education design is layered to ease the understanding of the specific roles of technologies, the actual system architecture implementations may be different.

The smart education design steps are specifically developed to be generic. This allows the steps to be used in many smart education designs. As the concept of smart education is new, until the concept is understood and utilized by many, the smart education system designs and the course designs will require support from smart education experts. These experts will customize these steps based on the specific needs of educational institutions. Therefore, in the early phases of smart education, support from smart education experts will be crucial.

The last steps of the smart education design are to evaluate design effectiveness and course effectiveness. In the early days of the smart education paradigm, smart education experts will help school administrators and course instructors in designing and constructing smart education systems. Furthermore, the students will likely provide feedbacks on the effectiveness of learning. As instructors get experience in smart education activities, they will better evaluate the smart education designs. Furthermore, most current smart education system proposals include various levels of learning and academic analytics capabilities. Tables 6 and 7 provide analyses of current smart education systems proposals. Tables 6 and 7 indicate such learning and academic analytics use. The data obtained from these components of smart education systems will help better understand the effectiveness of learning and systems. With all these feedbacks, experiences, and data the course designs based on the smart education paradigm will evolve and better serve student needs.

EDUCAUSE (2021) Horizon Report Teaching and Learning Edition lists key technologies and practices based on their importance in moving teaching and learning forward. These key technologies and practices are artificial intelligence, blended and hybrid course models, learning analytics, micro-credentialing, open educational resources, and quality online learning. While artificial intelligence and learning analytics may be considered technologies, the rest may be considered practices. Artificial intelligence is a broad term and the applications are countless. AI technology improves the capability of other technologies such as XR, smart classroom, educational data mining, educational robots, etc. Therefore, its effect is orthogonal. Learning analytics is already listed as enabling information technology for smart education. The technologies listed in the previous section cannot be exhaustive. New information and communication technologies are introduced every day. Therefore, as new technologies are introduced, they will take their place within the framework based on their role in contributing to smart education. Some of these technologies will be supportive technologies, some will be enriching and some others will be essential. We categorize technologies based on their contribution to smart education. 


\section{Conclusions}

In this study, based on an investigation of a wide range of information technologies supporting smart education, we developed a Smart Education Framework. The framework conceptually structures the technologies in a layered architecture. We also developed a smart education design approach based on the framework. Furthermore, we show how to use the framework and design approach to develop specific smart education course or lecture designs. To validate the smart education framework, we examined smart education systems reported in the literature. To identify smart education systems, we conducted a systematic literature search. The literature search results show that the smart education framework has the ability to describe smart education systems. Furthermore, we observe that there are only a handful of smart education system designs or implementations currently reported in the literature. This study contributes to the literature with a smart education framework, a smart education system design approach based on the framework, and an analysis of current smart education system design and implementations.

Expectations from applying information technology in education and training are high. However, the realizations of practical implementations are challenging (Buckingham, 2013). Organisation for Economic Co-operation and Development (OECD) Center for Educational Research and Education (CERI) states that teachers' use of ICTs often lags behind the technical skills required by students by the time they enter the workplace (OECD, 2016). Spector (2013) states that for the realization of education and training, we still need properly trained and dedicated teachers, designers, administrators, policymakers, and parents in addition to new and powerful educational technologies.

An OECD report states that technology is everywhere except at schools (OECD, 2008). While the report is a decade old, there is not much evidence to suggest this has changed. Our educational institutions are generally formal and bureaucratic. Information and communication technologies (ICT) are quick-paced and progressive. Our educational systems are static. ICTs are dynamic. There is an incompatibility by nature in terms of pace and dynamism between educational systems and ICTs. Thus, incorporating ICTs effectively into educational systems is inherently challenging. There are and will be many issues to overcome.

New information and communication technologies are creating a paradigm shift in education and training (Duffy, 2008). Furthermore, they support new learning approaches such as distance learning, mobile learning (m-learning), personalized learning, flipped and blended learning, social collaborative learning, game-based learning, etc. Information technologies coupled with new learning and teaching approaches will help to realize the concept of smart education. The framework outlined in this article has a technology focus while stressing the importance of a coherent combination of new or improved learning and teaching approaches with suitable technologies. As future work, this smart education framework may be extended. The extension shall focus on identifying how to combine various teaching and learning approaches with the most suitable technologies.

One of the emerging paradigms in education is Bring Your Own Device (BYOD) and Bring Your Own Technology (BYOT). In this paradigm, the students utilize their own computers, tablets, etc. during educational activities. How this paradigm will affect the 
notion of smart education and how smart education/learning frameworks will evolve are prospective future work studies.

\section{Abbreviations}

CERI: Center for educational research and education; ICTs: Information and communication technologies; IoT: Internet of things; ISO: International Standards Organization; IT: Information technology; OECD: Organisation for economic co-operation and development; SEF: Smart education framework; SES: Smart education systems; MOOC: Massive open online courses.

\section{Acknowledgements}

The views and conclusions contained herein are those of the author and should not be interpreted as necessarily representing the official policies or endorsements, either expressed or implied, of any affiliated organization or government.

\section{Authors' contributions}

There is only one author in this paper. The author conducted all the necessary research outlined in this paper. The author read and approved the final manuscript.

\section{Funding}

No funding is used for this research.

\section{Availability of data and materials}

All required data and materials are included in the manuscript.

\section{Declarations}

Competing interests

There are no competing interests.

Received: 29 July 2021 Accepted: 15 October 2021

Published online: 06 November 2021

\section{References}

Ali, M., Bilal, H. S. M., Razzaq, M. A., Khan, J., Lee, S., Idris, M., Aazam, M., Choi, T., Han, S. C., \& Kang, B. H. (2017). IoTFLiP: IoTbased flipped learning platform for medical education. Digital Communications and Networks, 3(3), 188-194. https:// doi.org/10.1016/j.dcan.2017.03.002

Alimisis, D. (2013). Educational robotics: Open questions and new challenges. Themes in Science and Technology Education, 6(1), 63-71.

Bajaj, R., \& Sharma, V. (2018). Smart education with artificial intelligence based determination of learning styles. Procedia Computer Science, 132, 834-842. https://doi.org/10.1016/j.procs.2018.05.095

Buckingham, D. (2013). Beyond technology: Children's learning in the age of digital culture. Wiley.

Chan, F. M. (2002). ICT in Malaysian schools: Policy and strategies. In Conference presentation. Workshop on the promotion of ICT in education to narrow the digital divide (pp. 15-22).

Duffy, P. (2008). Engaging the YouTube Google-eyed generation: Strategies for using Web 2.0 in teaching and learning. The Electronic Journal of e-Learning, 6(2), 119-130.

EDUCAUSE. (2021). 2021 EDUCAUSE Horizon report, teaching and learning edition. EDUCAUSE.

El Janati, S., Maach, A., \& El Ghanami, D. (2018). SMART education framework for adaptation content presentation. Procedia Computer Science, 127, 436-443. https://doi.org/10.1016/j.procs.2018.01.141

Erkollar, A., \& Oberer, B. (2016). The effects of the flipped classroom approach shown in the example of a master course on management information systems. The Online Journal of Quality in Higher Education-July, 3(3), 34-43.

Güzer, B., \& Caner, H. (2014). The past, present, and future of blended learning: An in-depth analysis of literature. Procedia Social and Behavioral Sciences, 116, 4596-4603. https://doi.org/10.1016/j.sbspro.2014.01.992

Hartono, S., Kosala, R., Supangkat, S. H., \& Ranti, B. (2018). Smart hybrid learning framework based on three-layer architecture to bolster up education 4.0. In 2018 IEEE international conference on ICT for smart society (ICISS) (pp. 1-5). https:// doi.org/10.1109/ICTSS.2018.8550028.

Hirsch, B., Al-Rubaie, A., Wang, D., Guttmann, C., \& Ng, J. W. (2012). Enabling the next generation learning environment. In 2012 IEEE/WIC/ACM international conferences on web intelligence and intelligent agent technology (vol. 3, pp. 352-356). https://doi.org/10.1109/WI-IAT.2012.156.

Hoel, T., \& Mason, J. (2018). Standards for smart education-towards a development framework. Smart Learning Environments, 5(1), 3. https://doi.org/10.1186/s40561-018-0052-3

Hua, M. T. A. (2012). Promises and threats: IN2015 Masterplan to pervasive computing in Singapore. Science, Technology and Society, 17(1), 37-56. https://doi.org/10.1177/097172181101700103

Hwang, G. J. (2014). Definition, framework and research issues of smart learning environments-a context-aware ubiquitous learning perspective. Smart Learning Environments, 1(1), 4. https://doi.org/10.1186/s40561-014-0004-5

IBM. (2009). Education for a Smarter Planet: The Future of Learning - ClO Report on Enabling Technologies. https://www. redbooks.ibm.com/redpapers/pdfs/redp4564.pdf

International Standards Organization. (2020). Retrieved 1 July 2020. https://www.iso.org/committee/45392.html. 
Jang, S. (2014). Study on service models of digital textbooks in cloud computing environment for SMART education. International Journal of $u$ - and e-Service, Science and Technology, 7(1), 73-82. https://doi.org/10.14257/ijunesst.2014.7. 1.07

Jemni, M., \& Khribi, M. K. (2017). The alecso smart learning framework. In E. Popescu, Kinshuk, M. K. Khribi, R. Huang, M. Jemni, N.-S. Chen, \& D. G. Sampson (Eds.), Innovations in smart learning (pp. 91-101). Springer. https://doi.org/10. 1007/978-981-10-2419-1_14

Jeong, J. S., Kim, M., \& Yoo, K. H. (2013). A content oriented smart education system based on cloud computing. International Journal of Multimedia and Ubiquitous Engineering, 8(6), 313-328. https://doi.org/10.14257/ijmue.2013.8.6.31

Jo, J., Park, J., Ji, H., Yang, Y., \& Lim, H. (2016). A study on factor analysis to support knowledge based decisions for a smart class. Information Technology and Management, 17(1), 43-56. https://doi.org/10.1007/s10799-015-0222-8

Jo, J., Park, K., Lee, D., \& Lim, H. (2014). An integrated teaching and learning assistance system meeting requirements for smart education. Wireless Personal Communications, 79(4), 2453-2467. https://doi.org/10.1007/s11277-014-1765-4

Jo, J., Yang, Y., \& Lim, H. (2012). Design of a structured plug-in smart education system. In S-S. Yeo, Y. Pan, Y. S. Lee, \& H. B. Chang (Eds.), Computer science and its applications (pp. 891-901). Springer. https://doi.org/10.1007/978-94-0075699-1 91

Kankaanranta, M., \& Mäkelä, T. (2014). Valuation of emerging learning solutions. In Proceedings of the EdMedia 2014_ World conference on educational media and technology, (pp. 168-172). Tampere, Finland. Association for the Advancement of Computing in Education (AACE). http://papers.iafor.org/wp-content/uploads/papers/acset2014/ ACSET2014_06578.pdf.

Kaufmann, H. (2003). Collaborative augmented reality in education. Institute of Software Technology and Interactive Systems, Vienna University of Technology. https://www.ims.tuwien.ac.at/publications/tuw-137414.pdf.

Kim, T., Cho, J. Y., \& Lee, B. G. (2013). Evolution to smart learning in public education: A case study of Korean public education. In T. Ley, M. Ruohonen, M. Laanpere, \& A. Tatnall (Eds.), Open and social technologies for networked learning (pp. 170-178). Springer. https://doi.org/10.1007/978-3-642-37285-8_18

Kim, Y., Soyata, T., \& Behnagh, R. F. (2018). Towards emotionally aware Al smart classroom: Current issues and directions for engineering and education. IEEEAccess, 6, 5308-5331. https://doi.org/10.1109/ACCESS.2018.2791861

Klopfer, E., Squire, K. \& Jenkins, H. (2002). Environmental detectives PDAs as a window into a virtual simulated world. In Proceedings of international workshop on wireless and mobile technologies in education (WMTE2002) (pp. 95-98). Växjö University, Sweden. https://doi.org/10.1109/WMTE.2002.1039227.

Knight, J. K., \&Wood, W. B. (2005). Teaching more by lecturing less. Cell Biology Education, 4, 298-310. https://doi.org/10. 1187/05-06-0082

Kobayashi, T., Arai, K., Sato, H., Tanimoto, S., \& Kanai, A. (2017). An application framework for smart education system based on mobile and cloud systems. IEICE Transactions on Information and Systems, 100(10), 2399-2410. https://doi. org/10.1587/transinf.2016OFP0001

Lage, M. J., Platt, G. J., \& Treglia, M. (2000). Inverting the classroom: A Gateway to creating an inclusive learning environment. Journal of Economic Education, 31(1), 30-43. https://doi.org/10.1080/00220480009596759

Lavine, J., \& Croome, R. (2018). United Arab Emirates. In A. S. Weber \& S. Hamlaoui (Eds.), E-learning in the middle east and north Africa (MENA) region (pp. 433-450). Springer. https://doi.org/10.1007/978-3-319-68999-9_19

Leonidis, A., Margetis, G., Antona, M., \& Stephanidis, C. (2010). ClassMATE: Enabling ambient intelligence in the classroom. World Academy of Science, Engineering and Technology, International Journal of Computer and Information Engineering, 4(6), 1058-1061.

Lisitsyna, L. S., Senchilo, M. S., \& Efimchik, E. A. (2020). Blended learning technology realization using a basic online course In V. L. Uskov, R. J. Howlett, \& L. C. Jain (Eds.), Smart education and e-learning 2020 (pp. 171-180). Springer. https://doi. org/10.1007/978-981-15-5584-8_15

Obasa, A. I., Eludire, A. A., \& Isaac, M. (2011). The architectural design of an integrated virtual classroom system. Research Journal of Information Technology, 3(1), 43-48.

Oberer, B. (2016). Flipped MIS'. The mobile flipped classroom approach shown in the example of MIS courses. International Journal of $u$ - and e-Service, Science and Technology, 9(3), 379-390. https://doi.org/10.14257/ijunesst.2016.9.3.36

Oblinger, D., \& Oblinger, J. (2005). Is it age or IT: First steps toward understanding the net generation. Educating the Net Generation, 2(1-2), 20.

OECD (2008). New millennium learners: Initial findings on the effects of digital technologies on school-age learners. Retrieved 1 July 2020. www.oecd.org/dataoecd/39/51/40554230.pdf.

OECD. (2016). Trends shaping education 2016. OECD Publishing. https://doi.org/10.1787/trends_edu-2016-en

Palloff, R. M., \& Pratt, K. (2002). Lessons from the cyberspace classroom: The realities of online teaching. Wiley.

Prince, M. (2004). Does active learning work? A review of the research. Journal of Engineering Education, 93, 223-231. https://doi.org/10.1002/j.2168-9830.2004.tb00809.x

Rakow, S. (2007). All means all: Classrooms that work for advanced learners. Middle Ground, the Magazine of Middle-Level Education, 11(1), 10-12.

Samsung. (2013). Samsung smart school an interactive and collaborative learning environment for the next-generation classroom. Samsung Brochure.

Shapsough, S., \& Zualkernan, I. A. (2020). A generic loT architecture for ubiquitous context-aware learning. IEEE Transactions on Learning Technologies. https://doi.org/10.1109/TLT.2020.3007708

Shoikova, E., Nikolov, R., \& Kovatcheva, E. (2017). Conceptualising of smart education. E+E, 52(3-4), 29-37.

Spector, J. M. (2013). Emerging educational technologies and research directions. Educational Technology \& Society, 16(2), $21-30$.

Spector, J. M. (2018). Smart learning futures: A report from the 3rd US-China smart education conference. Smart Learning Environments, 5(1), 1-10. https://doi.org/10.1186/s40561-018-0054-1

Strayer, J. (2012). How learning in an inverted classroom influences cooperation, innovation and task orientation. Learning Environments Research, 15(2), 171-193. https://doi.org/10.1007/s10984-012-9108-4

Zhu, Z. T., \& He, B. (2012). Smart education: New frontier of educational informatization. E-Education Research, 12, 1-13. 
Zhu, Z. T., Sun, Y., \& Riezebos, P. (2016a). Introducing the smart education framework: Core elements for successful learning in a digital world. International Journal of Smart Technology and Learning, 1(1), 53-66. https://doi.org/10.1504/ IJSMARTTL.2016.078159

Zhu, Z. T., Yu, M. H., \& Riezebos, P. (2016b). A research framework of smart education. Smart Learning Environments, 3(1), 4. https://doi.org/10.1186/s40561-016-0026-2

\section{Publisher's Note}

Springer Nature remains neutral with regard to jurisdictional claims in published maps and institutional affiliations.

Submit your manuscript to a SpringerOpen ${ }^{0}$ journal and benefit from:

- Convenient online submission

- Rigorous peer review

- Open access: articles freely available online

- High visibility within the field

- Retaining the copyright to your article

Submit your next manuscript at $\boldsymbol{\Delta}$ springeropen.com 